INTERNATIONAL

FOOD POLICY

RESEARCH

INSTITUTE

IFPRI

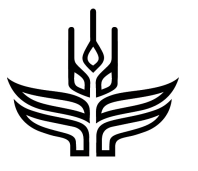

CGIAR

IFPRI Discussion Paper 01890

December 2019

From Index to Indemnity Insurance using Digital Technology

Demand for Picture-Based Crop Insurance

Francisco Ceballos

Berber Kramer

Markets, Trade, and Institutions Division 


\section{INTERNATIONAL FOOD POLICY RESEARCH INSTITUTE}

The International Food Policy Research Institute (IFPRI), established in 1975, provides research-based policy solutions to sustainably reduce poverty and end hunger and malnutrition. IFPRI's strategic research aims to foster a climate-resilient and sustainable food supply; promote healthy diets and nutrition for all; build inclusive and efficient markets, trade systems, and food industries; transform agricultural and rural economies; and strengthen institutions and governance. Gender is integrated in all the Institute's work. Partnerships, communications, capacity strengthening, and data and knowledge management are essential components to translate IFPRI's research from action to impact. The Institute's regional and country programs play a critical role in responding to demand for food policy research and in delivering holistic support for country-led development. IFPRI collaborates with partners around the world.

\section{AUTHORS}

Francisco Ceballos (f.ceballos@cgiar.org) is an Associate Research Fellow in the Markets, Trade, and Institutions Division of the International Food Policy Research Institute (IFPRI), Washington D.C.

Berber Kramer (b.kramer@cgiar.org) is a Research Fellow in the Markets, Trade, and Institutions Division of IFPRI, Washington D.C.

\footnotetext{
Notices

${ }^{1}$ IFPRI Discussion Papers contain preliminary material and research results and are circulated in order to stimulate discussion and critical comment. They have not been subject to a formal external review via IFPRI's Publications Review Committee. Any opinions stated herein are those of the author(s) and are not necessarily representative of or endorsed by IFPRI.

${ }^{2}$ The boundaries and names shown and the designations used on the map(s) herein do not imply official endorsement or acceptance by the International Food Policy Research Institute (IFPRI) or its partners and contributors.

${ }^{3}$ Copyright remains with the authors. The authors are free to proceed, without further IFPRI permission, to publish this paper, or any revised version of it, in outlets such as journals, books, and other publications.
} 


\title{
From Index to Indemnity Insurance using Digital Technology: Demand for Picture-Based Crop Insurance
}

\author{
Francisco Ceballos ${ }^{\mathrm{a}, *}$ and Berber Kramer ${ }^{\mathrm{a}, \uparrow}$
}

December 2, 2019

\begin{abstract}
Production risk is pervasive in agriculture, yet smallholder farmers lack access to quality insurance. This is due to asymmetric information in markets for indemnity insurance, and high basis risk, limited trust, and poor understanding of index-based insurance. Digital technologies can help overcome these challenges by improving crop monitoring and yield prediction, allowing insurers to provide products that move towards indemnity insurance. Although this can potentially improve demand, it also comes at the risk of introducing adverse selection. We analyze this trade-off by eliciting willingness to pay for both indexbased insurance and picture-based insurance (PBI) for visible crop damage through incentivized auctions with smallholder farmers in northwestern India. Participants reveal a higher willingness to pay for PBI than for index-based coverage. Although at commercial rates, demand remains low for either product, PBI improves demand at the subsidized premium levels maintained by India's national insurance scheme. Moreover, we find no evidence of adverse selection. We conclude that digital technologies can facilitate a shift from index-based insurance to indemnity insurance. By reducing basis risk and strengthening trust and understanding, this can improve demand for crop insurance.
\end{abstract}

JEL codes: G220, O13, O16, Q14

Keywords: risk and insurance; mobile technology; adverse selection; willingness to pay

a) Markets, Trade and Institutions Division, International Food Policy Research Institute (IFPRI), 1201 Eye Street, NW, Washington, DC 20005. *F.Ceballos@cgiar.org `B.Kramer@cgiar.org.

Acknowledgements: We gratefully acknowledge Braulio Britos, Amandeep Chhabra, and Matthew Krupoff for excellent research assistance; Azad Mishra and Siddhesh Karekar from HDFC for pioneering the implementation of PBI; and the Borlaug Institute for South Asia for their dedication to data collection. We received valuable suggestions from Chris Barrett, Glenn Harrison, Dean Karlan, Craig Mcintosh, Chris Udry, as well as seminar participants at Göttingen University, ZEF Bonn, and numerous conferences and workshops organized by (among others) the International Fund for Agriculture and Development (IFAD), Innovation for Poverty Action (IPA), Georgia State University's Center for the Economic Analysis of Risk (CEAR), M.S. Swaminathan Research Foundation, Madras School of Economics, and the International Labor Organization (ILO). This work was undertaken as part of the CGIAR Research Program on Policies, Institutions, and Markets (PIM) led by the International Food Policy Research Institute (IFPRI). Funding support for this study was provided by PIM and the International Initiative for Impact Evaluation (3ie). This paper has not gone through IFPRI's standard peer review procedure. The opinions expressed here belong to the authors, and do not necessarily reflect those of PIM, 3ie, IFPRI, or CGIAR. 


\section{Introduction}

Billions of rural households worldwide depend on agricultural incomes for subsistence. Yet, agriculture is among the riskiest economic activities. Weather occurrences and other natural hazards such as pests and diseases can induce large losses to crops, disproportionately affecting poor farming households' future through reduced food consumption or schooling (Dercon and Hoddinott, 2004; Barrett and McPeak, 2006). Moreover, large disruptive effects of extreme weather events on production may be subsequently transmitted to other layers of the agricultural value chain (e.g., traders, wholesalers, processors, suppliers) and to rural financial markets (through loan defaults, illiquidity). To reduce their exposure to these risks, farmers tend to diversify their livelihoods by investing in low-risk yet low-return activities, impeding them from capturing the full range of benefits from specialization, and holding back investment into riskier opportunities with a higher expected income, causing an efficiency loss. ${ }^{1}$

Formal insurance is a natural solution to some of these problems, but agricultural insurance penetration in rural areas of developing countries has been historically very low. Indemnity insurance, which requires on-site loss verification by a specialized adjuster, is expensive to provide in remote areas and subject to information-asymmetry problems such as moral hazard or adverse selection, further increasing premiums (Hazell, Pomareda, and Valdes, 1986). In contrast, index insurance, which compensates the farmer according to the value of an objectively-measured proxy for losses (the 'index'), offers a promising alternative as index-based claims settlement is faster and less expensive than on-site indemnification. Moreover, since payouts do not depend on an individual farmer's riskiness or actions, there is no asymmetric information. Demand for index-based insurance has, however, been low due to basis risk, or the inability of an index to adequately capture crop damage at individual plots, along with farmers' lack of trust and understanding of index insurance (Cole et al., 2013; Matul et al., 2013).

To reduce basis risk, index insurance schemes have started relying in recent years on digital technologies and remote sensing capable of identifying damage at a more localized level, such as high-resolution satellites, drone imagery, and ground pictures taken with regular smartphone or tablet cameras. India's national crop insurance scheme, for instance, has started

\footnotetext{
${ }^{1}$ Although rural households can resort to informal risk coping strategies such as holding savings or semi-liquid assets that can be easily sold in times of need, borrowing from informal sources, and relying on gifts from social or family networks, these strategies are costly, and have limited potential to mitigate risks (Townsend, 1994).
} 
exploring the use of these technologies to monitor crop health, predict yields, and indemnify losses at increasingly granular levels. The expectation is that by using technology to lower basis risk, insurance will become substantially more appealing to farmers, boosting demand and strengthening impacts of crop insurance schemes. At the same time, impacts on demand will be limited when farmers face other barriers to enroll, for instance liquidity constraints or limited trust (Belissa et al., 2019), or self- and other-commitment problems to save for insurance premiums (Gine et al., 2018; Janssens, Kramer and Swart, 2017). Further, when identifying crop losses for individual farmers or plots, insurance coverage starts moving towards indemnity-based products, which may re-introduce issues around adverse selection that limited the supply of indemnity-based insurance in the first place.

In this paper, we therefore analyze the effects on demand and adverse selection of an innovative remote sensing technology: picture-based crop insurance (PBI). PBI relies on a stream of plot-level smartphone pictures of insured crops, taken by farmers from sowing to harvest, to document crop damage and pre-damage growth and management of insured crops. Compared to indemnity-based insurance, this approach helps minimize the costs of loss verification, as it eliminates the need to send an insurance agent to verify a farmer's claim in person. A formative evaluation of PBI, targeting 750 smallholder farmers from six districts in Haryana and Punjab, India, indeed shows the feasibility of PBI: crop damage is visible in farmers' regular smartphone pictures and picture-based loss assessment can identify severe damage more accurately than other index-based insurance products, considerably lowering basis risk (Ceballos, Kramer, and Robles, 2019). ${ }^{2}$ This paper tests whether PBI improves demand for crop insurance and whether this insurance approach brings about more adverse selection relative to regular index-based products.

To that end, we rely on a field experiment conducted one season after the formative evaluation of PBI among a subsample of 100 farmers who had participated in that formative evaluation, also interviewing the main female decisionmaker in their household. As a follow-up to the prior season, we revisited these 100 households, and elicited incentivized measures of their

\footnotetext{
${ }^{2}$ By assessing crop damage at an individual level, PBI could potentially provide incentives to farmers for reducing the use of appropriate but costly management practices such as pest management, weeding, and inputs such as seeds, fertilizer, or labor; or even induce them to commit fraud in order to receive insurance payouts. In a separate article, we test for such moral hazard and insurance fraud during the formative evaluation and find no evidence for such behavior (Ceballos and Kramer, 2019).
} 
willingness to pay (WTP) for index-based insurance versus PBI. Specifically, using the BeckerDegroot-Marschak (BDM) auction mechanism, we obtained each farmer's maximum WTP for four alternative products or treatments (with within-subjects variation): unconditional weather index-based insurance coverage (WBI); WBI coverage conditional on following PBI picturetaking protocols, to assess participants' (positive or negative) valuation of having to send in crop pictures regularly; WBI plus PBI coverage, to assess demand for improved coverage; and a PBI only product, to study whether participants perceive WBI and PBI as complements or substitutes.

We find that adding PBI coverage within a weather index-based insurance product improves WTP for insurance, and the WTP for a bundled product is significantly higher than the WTP for either product alone, indicating that farmers regard PBI as a valuable complement in weather-index based insurance products. Moreover, conditioning weather index-based insurance coverage on following PBI picture-taking protocols does not crowd out demand, suggesting that farmers do not perceive a large cost in time or effort around taking regular pictures at their plot. Although the average WTP for all four products remains well below commercial insurance premium rates, PBI does improve demand when offered at the subsidized premium rates to which farmers are exposed in the context of India's national insurance scheme. This underscores the need to embed a product such as PBI within existing insurance schemes, making current insurance solutions that struggle with basis risk and poor farmer engagement more attractive. We also compare WTP among male and female respondents but find no gender differences in insurance valuation.

We test for adverse selection through positive correlation tests (Chiappori and Salanié, 2000), relying on two separate identification strategies. First, we correlate a respondent's valuation of PBI coverage with indicators that proxy for the farmer's risk of experiencing crop damage, and thus of receiving insurance payouts, including measures of past damage and yields. In the presence of adverse selection, farmers with higher risk will have a higher valuation of PBI, resulting in a positive correlation. Second, we test whether farmers, in choosing which of their different plots to enroll, select a plot with an increased probability of crop damage, due to for instance poor irrigation access or soil quality. We measure these characteristics prior to WTP elicitation and subsequent insurance coverage, so that our estimate of adverse selection is 
unbiased by moral hazard or treatment effects. ${ }^{3}$ To our surprise, we find no evidence of adverse selection in our sample, regardless of whether we use the first or the second identification strategy. We discuss alternative interpretations of these results in the concluding section.

This paper relates to two strands of the literature. First, we add to the literature on demand for crop insurance, which highlights basis risk in existing index-based insurance schemes as one of the main barriers to insurance enrollment and subsequent agricultural risk management (Clarke and Kalani, 2011; Cole et al., 2013; Hill, Hoddinott and Kumar, 2013). We contribute by showing that a technology-based innovation that lowers basis risk can indeed improve demand, but only at subsidized premium rates. Although PBI improves the willingness to pay for crop insurance, demand may remain low even for this type of product when offered at commercial premium rates due to other barriers, for instance liquidity constraints, limited trust in insurance providers, and reliance on informal risk sharing arrangements.

Second, we relate to the literature on adverse selection. Adverse selection is considered a threat to the sustainability of multi-peril crop insurance, since higher enrollment of those who are more prone to damage would raise insurance premiums, crowding out demand from lower-risk and poorer farmers, jeopardizing impacts. Theory, however, suggests that selection into insurance is not necessarily adverse, as individuals will also select based on characteristics associated with precautionary behaviors and lower risks. Several studies find that not only highrisk individuals but also individuals who take precautionary and risk-reducing actions are more likely to enroll in insurance, and such advantageous selection often offsets any adverse selection (De Meza and Webb, 2001; Finkelstein and McGarry, 2006; Doiron, Jones and Savage, 2008; He et al., 2018). Our finding of zero selection on risk characteristics is consistent with this literature, and with findings that there cannot be adverse selection if there is low demand (Banerjee, Duflo and Hornbeck, 2014). ${ }^{4}$

\footnotetext{
${ }^{3}$ If households are offered different insurance premiums, and the variation in the insurance premium is exogenous, an alternative approach to circumvent such biases is to use a price test, in which claims data are compared between households enrolling at a high premium and households enrolling at a low premium to obtain a monetary measure of adverse selection (Polimeni and Levine, 2012). Akerlof (1970) shows that in the presence of adverse selection, the high-premium sample will have higher claims than the low-premium sample, and the difference in claims will reflect the cost of adverse selection. We will apply this method in future research.

${ }^{4}$ Cohen and Siegelman (2010) provide an overview of the literature testing for adverse selection in insurance markets. Several studies have empirically tested for adverse selection in crop insurance, including He et al. (2017), Jensen, Mude and Barrett (2018), Just, Calvin and Quiggin (1999), and Makki and Somwaru (2001).
} 
Combined, these findings indicate that farmers value the use of digital technologies in strengthening index-based insurance solutions, and although these improved insurance products offer indemnity-based coverage, adverse selection does not appear to represent an important obstacle in using this approach to cover farmers against natural hazards at a low cost.

The remainder of this paper proceeds as follows. Section 2 discusses the project's context, the data used, and the WTP elicitation methodology. Section 3 analyzes the WTP data and discusses the effects of PBI on farmer demand while Section 4 tests the adverse selection hypotheses. Section 5 concludes.

\section{Methods}

\subsection{Context}

Crop insurance in India has a long and complex history (see Cariappa, Lokesh and Ramesh, 2017 and references therein for an overview). Starting in the 2016 Kharif (monsoon) season, the Government of India launched a nationwide crop insurance scheme called Pradhan Mantri Fasal Bima Yojana (PMFBY). The PMFBY expanded subsidized multi-peril crop insurance with mandatory coverage for farmers taking an agricultural loan from an official credit institution. The scheme is heavily subsidized, with the farmer having to pay a maximum premium of 2 percent of the sum insured for Kharif crops, 1.5 percent for Rabi crops, and 5 percent for annual commercial and horticultural crops. Claims settlement occurs through several mechanisms, but mainly through an area-yield index-based approach, which triggers payouts when average yields within a cluster of villages (measured through state-operated crop cutting experiments) fall below a historical threshold. The scheme also has an indemnity-based component, providing coverage for prevented sowing, mid-season adversities caused by covariate weather shocks, localized calamities such as flooding, hail storms and landslides, and post-harvest losses due to perils such as excess rainfall. Thus far, payouts have, however, been mainly triggered based on the area-yield index.

To implement this area-yield index, states need to randomly select, at the time of the harvest, at least four sites per Gram Panchayat (a cluster of villages) to measure yields for every crop that is covered through the PMFBY. This is a daunting operation, and challenges in the monitoring and implementation of the crop cutting experiments have led to disputes and delays in claims settlement. Recognizing this, the PMFBY has provisions for the use of innovative 
technology throughout the insurance process, from enrollment to claims settlement. This includes the use of smartphone pictures to capture and upload data of crop cutting experiments, which is currently undergoing testing; the use of satellite imagery to reduce the number of crop cutting experiments that states need to conduct; as well as the use of drones and other remote sensing technologies to provide coverage for prevented sowing, mid-season adversities, localized calamities, and post-harvest losses. The implementation of remote sensing for yield estimation faces a number of challenges, including cloud cover during the main production season, multicropping and small plot sizes, and a need for ground truth data, which ground pictures can provide. In this context, PBI stands as a promising digital technology to support existing PMFBY activities.

This paper builds upon data collected through the Picture-Based Insurance (PBI) project, which was launched during the 2016-17 Rabi (winter) season, targeting 750 wheat farmers from six districts and 50 villages in the states Haryana and Punjab, India to assess the feasibility of PBI. Wheat is the main crop grown during the winter season in these two states, and given that irrigation is widespread, drought is not a major risk to wheat. Instead, major risks include excess rainfall, hail, extreme heat, and pests and diseases. In Haryana, PMFBY coverage for major crops including wheat is available, whereas Punjab has decided not to join the scheme, and relies on ex-post disaster relief and loan waivers for natural calamities instead.

Here, we will use data on farmers' willingness to pay for insurance products that would cover production losses in the 2017-18 Rabi season at subsidized rates. Willingness to pay was elicited in July 2017 as a follow-up to a first season of implementation and data collection. We will also use baseline and endline surveys from the previous season, conducted during August 2016 and April 2017, respectively. The baseline survey inquired about an array of farm and household characteristics, such as a roster of plots and specific plot-level characteristics, cultivation practices, input use, adoption of several agricultural technologies, household composition, income, risk attitudes, and perceptions. The endline survey gathered further data on cultivation practices over the Rabi 2016/17 season, including input use and self-reported wheat output.

The WTP elicitation was conducted for a subsample of 100 farmers from the sample of participants in the initial season. They had all received a phone with the request to take repeat pictures of the exact same area of one of their plots through 'WheatCam', a dedicated Android 
application. The app served to ensure that the picture was taken in the same location by showing a transparent image of the initial picture (referred to as "ghost" image) that allowed the user to overlap fixed background elements such as trees or buildings. The study protocol requested farmers to take pictures two to three times a week, from sowing to harvest, ideally between the hours of $10 \mathrm{am}$ to $2 \mathrm{pm}$ for optimal lighting conditions. The smartphone app uploaded the pictures directly to a server, where at the end of the season, three wheat experts accessed the images to assess for each site the level of damage visible in the pictures.

Conditional on taking regular pictures, all farmers received free insurance for one acre of wheat. All farmers were entitled to weather-index based insurance (WBI), designed to cover against the risk of excess rainfall and extreme heat in the period from February to April. These hazards were the main weather risks reported by farmers that could be measured through weather stations. They were based on focus group discussions and key informant interviews conducted during the intervention design. In 25 randomly selected villages, farmers received, in addition to WBI, the PBI product, which covered the farmer's crop against any residual visible damage in their crops, as assessed by the three wheat experts. Sites with damage above $20 \%$ received payouts, up to a maximum insured sum of Rs. $13,000 .^{5}$ In case both WBI and PBI triggered payouts, farmers received the payout from the component with the highest amount. See Ceballos, Kramer and Robles (2019) for further information on the research design and findings of this first season.

\subsection{Sample recruited for the willingness to pay experiment}

During July 2017, after the 2016/17 Rabi study season but several months before the start of the following season (November-December), we elicited the willingness to pay (WTP) for different insurance products from a subsample of 100 farmers in 20 villages. To ensure familiarity with the picture-taking protocol, only villages with at least seven participating farmers (who had taken at least one repeat picture during the season) were considered. Amongst these villages, we selected those villages with the highest levels of engagement (as measured by the total number of pictures taken in that village). Finally, within each village, we ranked the top seven farmers in

${ }^{5}$ Payout categories were as follows: Rs. 3,900 when assessed damage was between 20 to 50 percent; Rs. 7,800 when assessed damage was between 50 to 75 percent; and Rs. 13,000 when assessed damage was above 75 . 
terms of their engagement in the first season. To reward active participation, the top five were invited to participate in the study, whereas the other two farmers served as replacements.

Table 1 summarizes the characteristics of households that participated in the baseline survey and compares them to those from the WTP elicitation sample given that the sampling procedure may have introduced a selection bias. The 736 households who completed a baseline interview are representative of households planning to cultivate at least two acres of wheat in the 2016/17 Rabi season, having relatively smaller landholdings, and owning a smartphone in our six study districts in Haryana and Punjab. The average farmer is 39 years of age, cultivates about 9 acres of land, and lives in a household of around 6 individuals. Further, 44 percent of farmers have completed tertiary education and 10 percent belong to a scheduled or other backward caste. On average, 94 percent of households own the insured plot. They obtain 84 percent of their income from crop cultivation, and wheat represents close to 40 percent of their annual crop income. Average wheat yields are 19.6 quintals per acre and farmers cultivate wheat during the Rabi season in nearly all plots. Finally, more than three-quarters of respondents are used to taking pictures with their smartphones and report having regular network signal in their plots.

Columns (2) and (3) summarize these characteristics for the sample of 636 farming households who did not participate in the WTP experiment, versus the 100 households who did participate. Column (4) summarizes the difference in means between the two samples. Although we observe a few differences in household and farmer characteristics, most differences are not statistically significant. The only exception is that selected households had slightly fewer members than non-selected households. Under the assumption that engagement during the initial season was not driven by unobserved characteristics that are uncorrelated with the observed characteristics presented in Table 1, the results from our analyses should be broadly applicable to the population of smallholder farming households in our study districts, as the sampling prior to the initial season was representative of this population. In addition, our main analysis relies on a comparison of willingness to pay within subjects. We will test for an interaction effect of prior study engagement and the relative valuation of PBI versus weather index-based insurance to assess whether our findings will be informative for the relative demand for PBI among smallholder farmers in the region, not only those who were sampled into the study because of their prior engagement. 


\subsection{Experimental design}

For each participant in the experiment, we elicited WTP for four different products:

- WBI only: offering coverage against excess rainfall and above-normal temperatures, without having to take pictures of the crop.

- WBI + pictures: identical to the WBI only product but paying out conditional on the farmer taking pictures of the crop regularly.

- WBI + PBI: identical to the $W B I+$ pictures product but providing additional coverage against damage visible in the pictures.

- PBI only: identical to the $W B I+P B I$ product but excluding coverage against excess rainfall and above-normal temperatures that is not visible in the pictures.

This within-subject design allows us to analyze several aspects of the demand for these products. First, it is straightforward to assess the stand-alone valuation of the different individual products, $P B I$ only, WBI only, and the $W B I+P B I$ bundle. Second, comparisons between these valuations can provide important insights regarding farmers' perceptions of the different insurance components. For instance, the difference in WTP between WBI + pictures and WBI only reveals a participants' utility (or disutility) derived from having to take pictures regularly of their crop, providing an objective valuation of this implicit requirement for PBI coverage. Moreover, the difference in WTP between $W B I+P B I$ and $W B I+$ pictures indicates how much participants are willing to pay for extra PBI coverage, when already covered by the more traditional WBI. Finally, comparing the sum of the WTP for the stand-alone PBI only and WBI only products with the WTP for the bundled $W B I+P B I$ product sheds light on the extent to which WBI and PBI are substitutes or complements.

To elicit WTP, we adjusted the Becker, Degroot and Marschak (1964) method (henceforth, $\mathrm{BDM})$ as follows. An enumerator explained that the participant had been selected to receive a promotional discount on one of four insurance products for one acre of wheat in the upcoming Rabi season, and asked him/her to choose one of the household's plots to enroll in insurance should they purchase the product. This element of the study design allows us to compare the characteristics, particularly those that proxy for the risk of crop damage, of the plot that the 
household chooses to enroll with those of the household's other plots, informing the extent of adverse selection at the plot level in this context.

Next, the participant selected a scratch card from a pile (see Figure 1 for an example) with illustrations of the four insurance products and two boxes covered with metallic scratch-off ink. The enumerator briefly explained the characteristics of each product and asked the participant to write down his/her maximum WTP for each of the products in the space below the illustration, before scratching off the ink to reveal the "Product" and "Special premium offer" boxes. The "Product" box indicated which of the four products s/he would be able to purchase, while the "Special premium offer" box indicated the price at which s/he could obtain that product. The contents of both boxes were randomly assigned in advance, together with the ordering of the products (to control for product order effects). ${ }^{6}$ If a participant's WTP for the selected product was at or above the special premium offer, s/he would be required to purchase the product at that special premium (and not at his/her full WTP). Otherwise, the participant would not receive that product and would not be able to purchase any insurance at that point in time.

The BDM method has been used extensively in the WTP literature (Bageant and Barrett, 2017; Cole, Giné and Vickery, 2017; Cole, Stein and Tobacman, 2011; Stein and Tobacman, 2016) because it incentivizes respondents to reveal their true maximum WTP. Writing down a lower amount could result in being unable to buy the product for a price at which the respondent would like to buy it. Vice versa, stating a higher amount could result in having to buy the product at too high of a price. Since the participant knows in advance that the random price is already printed under the scratch-off ink, this application of the BDM method avoids one of the common objections against it: that a participant may not reveal his true valuation due to an underlying fear of the experimenter (or software) manipulating the price after the bid is made.

The entire procedure was explained in advance and a practice session-with a real practice card-was conducted before the real session took place. Participants were told that, should they win the product, they would need to provide the field staff with a check for the special premium offer amount, dated for October (before the start of the upcoming Rabi season). Practice rounds were conducted with both the main male and the main female decisionmakers of the household separately, that is, without the presence of the other decisionmaker. The real round was

\footnotetext{
${ }^{6}$ In half of the cards, the order was "WBI only" - "WBI + Pictures" - "WBI + PBI" - "PBI only", while in the other half exactly the opposite (as in Figure 1).
} 
conducted with the two decisionmakers together. Unless stated otherwise, our analyses will focus on the willingness to pay as revealed during the real round with incentives to report truthfully. All sessions were conducted in the local language, either in Hindi or in Punjabi. See Appendix 1 for an English version of the full script used in the study.

\section{Average demand}

PBI can help strengthen crop insurance by providing comprehensive insurance coverage with considerably lower levels of basis risk than alternative products, but it does involve higher costs in terms of farmer's time spent in taking repeat pictures, mobile data needed to upload the images, data infrastructure to handle the uploaded images, and conducting loss assessments for those farmers filing a claim. We therefore analyze the tradeoff between the additional value that farmers assign to the improved coverage, and the product's additional costs. We also compare farmers' valuation of PBI with current premium rates in the PMFBY, which is the nationwide program that provides multiple-peril coverage. We are doing this in order to understand whether PBI could potentially improve voluntary take-up at subsidized premium rates, or, alternatively, allow governments to reduce subsidy levels required to sustain high take-up, freeing up public resources for other purposes.

\subsection{Willingness to pay for insurance}

Figure 2 presents the average willingness to pay for each of the four products offered - that is, the average amount that farmers wrote down as the maximum amount they would pay for each product during the final, real-stakes round. ${ }^{7}$ A few interesting findings emerge from the figure.

First, farmers do value the enhanced coverage provided by PBI as a standalone product. While the average farmer is willing to pay 5.7 percent of the sum insured (Rs. 736) for the WBI only product, he is willing to pay 6.7 percent (Rs. 866) for the PBI only product, a statistically significant difference of Rs. 130 (or an increase in WTP of 17.7 percent). Moreover, farmers show interest in the bundled product, with an average WTP of 8.1 percent of the sum insured (Rs. 1,052). This is arguably related to the complementarity between the two insurance products,

\footnotetext{
${ }^{7}$ Henceforth, we use 'farmer' for clarity, while in practice the WTP decisions in this final incentivized round may have been made together by both male and female decisionmakers in the household, as described in Section 2.3 .
} 
where PBI can provide coverage for visible damage in a time-lapse of pictures and WBI can help close the coverage gap in terms of non-visible damage, such as high temperatures close to harvest time.

In order to get a sense of farmers' perceptions around the effectiveness of these alternative products, Table 2 shows the average self-reported (i) probability of receiving a payout if there is damage in the crop, (ii) estimated monetary payout if the product pays out, and (iii) overall expected payout if there is damage in the crop (a combination of the former two measures). Farmers do perceive products including PBI as being able to better capture damage when it occurs and providing higher payouts in these cases, translating into lower downside basis risk. ${ }^{8}$ The differences in farmers' perceptions about PBI products in relation to the WBI only product are statistically significant. All in all, the average farmer expects the $W B I+P B I$ product to pay about double the amount of the WBI only product. Such perceptions may potentially be an important driver of the higher valuation of the $P B I$ only and $W B I+P B I$ products discussed above, a hypothesis which we formally test in the following subsection.

Contrary to our expectations, farmers do not seem to strongly dislike having to take pictures. The willingness to pay for the $W B I+$ pictures product - which requires farmers to take pictures of their crops regularly throughout the Rabi season - is only 0.2 percentage points (Rs. 21) lower than that of WBI only, an economically-small and statistically-insignificant difference. This finding is in line with anecdotal evidence from farmers' informal conversations with field staff, where some farmers pointed out to an opposite effect: visiting the field more often is of value to them since it allows them to identify issues with the crop and thus initiate required actions earlier.

To assess the extent of this side effect of PBI, Appendix Table B1 shows farmer responses on additional questions in the Rabi 2016-17 endline survey aiming to capture farmers' perceptions around having to take pictures regularly. The time needed to take the pictures does not seem to be a salient issue: 97.1 percent of farmers did not report time as a challenge for taking pictures (Panel A). When asked about the degree to which they like or dislike different activities around taking pictures, more than 90 percent of farmers reported being either

\footnotetext{
${ }^{8}$ Downside basis risk represents events where a farmer's crop is damaged, but the insurance product does not pay out. Upside basis risk, on the other hand, corresponds to the situation where the crop is not damaged, yet the insurance product pays out. The farmers in our sample assigned no probability to an upside basis risk event.
} 
indifferent or liking (i) having to take pictures themselves, (ii) having to take pictures three times a week, and (iii) visiting the plot often; with only three farmers reporting to "really dislike" these aspects of PBI (Panel B). Finally, more than half (51.7) of the farmers reported "detecting problems in crop sooner" as one of the advantages of taking pictures, and 20 percent of these reported it as being the main advantage, above receiving a smartphone, insurance, or a monthly data plan (Panel C).

This latter finding could be seen as surprising: if visiting the plot more often would be an easy way for farmers to increase their productivity and profitability, we would expect a farmer interested in profit maximization to already do so even if not having to comply with a picturetaking protocol. One hypothesis is that farmers recognize the value of visiting their fields and would like to visit their fields more often in the future, but reverse this preference as the future becomes present, due to a time inconsistency in preferences. The threat of a reminder from field staff, and ultimately of losing their right to participate in the study, may have been a commitment device for farmers (c.f. Bryan, Karlan and Nelson, 2010), nudging more frequent field visits.

The average WTP presented in Figure 2, however, conceals the extent of heterogeneity in farmers' valuation and does not allow to understand demand in real market conditions at different premium rates. Figure 3 therefore shows an aggregate demand curve for each of the four products offered to farmers. In line with the statistics presented in Figure 2, demand is consistently stronger for $P B I$ only (relative to $W B I$ only) across the whole range of valuations. Moreover, the demand for the bundled product $(W B I+P B I)$ is well above that for the standalone products. For instance, at a premium equal to 5 percent of the coverage amount, the after-subsidy premium for commercial crops under PMFBY, 59 percent of farmers would be willing to purchase the $W B I$ only product, while 68 and 75 percent, respectively, would be willing to purchase the PBI only and $W B I+P B I$ products.

Without government subsidies, these products will need to be offered in the market at a higher premium rate. During the Rabi 2016-17 season, the commercial premium at which the WBI only product was offered by HDFC Ergo was Rs. 3,140 or around 24 percent of the sum insured. In the case of the $W B I+P B I$ product, the commercial premium increased by Rs. 630 , 
for a total of Rs. 3,770 or 29 percent of the sum insured. ${ }^{9}$ Figure 3 shows that at these premium rates, no farmer would be interested in purchasing the product. As a result, at commercial premiums, PBI does not improve demand for insurance. During the more recent Rabi 2017-18 season, the first season's experience led HDFC Ergo to design a modified $W B I+P B I$ product with a new pricing method, which resulted in considerably lower premiums equal to 14.5 percent of the coverage amount for both the $W B I+P B I$ product and the $W B I$ only product. However, even at the Rabi 2017-18 premiums, under ten percent of farmers would be willing to purchase PBI.

While such dim levels of demand for insurance may seem discouraging, they need to be regarded in the general context of crop insurance in India. Under the PMFBY, farmers can purchase insurance for wheat at 1.5 percent of the sum insured per season, creating an implicit anchor value for other crop insurance premiums, which may have biased farmers' WTP downwards. At the same time, if PBI were to be included as a top-up product for additional coverage under the PMFBY umbrella, government premium subsidies could be reduced such that farmers pay an out-of-pocket premium rate of for instance 5 percent of the sum insured, which is equivalent to premiums paid for insurance products for commercial crops, without significantly crowding out demand, given that the demand for PBI only and bundled products is less price sensitive than it is for the WBI only product.

\subsection{Determinants of farmers' WTP}

To better understand the underlying drivers of farmers' valuation of insurance, we assess the extent to which socio-demographic factors explain the observed WTP among farmers. Factors potentially related to adverse selection are not included here but analyzed and discussed in the next section.

In Table 3 we show ordinary least squares estimates of farmers' WTP as a function of an array of farmer and other characteristics. Column (1) formalizes the results discussed in Figure 2: requiring farmers to take regular pictures in their plots reduces the average WTP for insurance by

\footnotetext{
${ }^{9}$ It is important to note that, Rabi $2016 / 17$ being the first season a product such as PBI was offered in the area and given the lack of historical disaggregated yield data for pricing, this premium included an additional uncertainty premium. In future seasons, as more historical data becomes available and the scale of the product increases, PBI premiums would be adjusted to reflect actual loss occurrence and the uncertainty premium reduced. Thus, in our study area, Rs. 630 is most likely an upper bound of the amount by which the insurance premium should increase when adding PBI coverage to a WBI product.
} 
around Rs. 21 but this is not statistically different from zero, while the increased valuations for $P B I$ only and $W B I+P B I$ with respect to $W B I$ only are economically and statistically significant. Column (2) adds as a control a dummy variable for the farmer having had experience with PBI in the preceding season (i.e., living in a village assigned to PBI treatment during the initial season). Prior experience lowers the willingness to pay for insurance. This finding could be owing to a selection effect, in that the PBI treatment may have induced a different type of farmer-those who are more liquidity-constrained and valued free insurance coverage the most, but would also be able to pay the least for insurance coverage on their own - to send in more images during the initial season. Whether this is the case remains an open question for further research.

The remaining columns control for common household and farmer characteristics potentially related to the demand for insurance. In Column (3), we add a farmer's risk aversion, measured through an unincentivized Binswanger lottery, framed as a risk game in which the farmer had to choose among five alternative seeds with different risk exposure to bad weather. ${ }^{10}$ In line with the index insurance literature (Clarke and Kalani, 2011; Cole et al., 2013; Hill, Hoddinott and Kumar, 2013; and Hill, Robles and Ceballos, 2016), more risk-averse farmers indicate a lower WTP. Conceptually, since index insurance brings about additional uncertainty due to basis risk (i.e., the possibility of not getting a payout in the presence of damage), a sufficiently risk-averse farmer may forgo insurance (Clarke, 2016). Since PBI reduces basis risk compared to WBI, we would expect this effect to disappear, giving room to the classical insurance result of higher risk aversion leading to higher propensities to purchase insurance. To test this hypothesis, Column (4) interacts risk aversion with product dummies. Indeed, risk aversion has less of a negative effect on WTP for the two products that include PBI coverage, offering partial support to the above hypothesis.

In addition to risk aversion, receiving a payout has been found to be an important determinant of repeat insurance purchases in the literature (Cole, Stein and Tobacman, 2014; Hill, Robles and Ceballos, 2016; Karlan et al., 2014; and Stein, 2011). For this reason, we include in Columns (3), (4) and (5) a dummy variable that takes the value 1 if a farmer received an insurance payout during the Rabi 2016/17 season and 0 otherwise. We find that having received a payout increases WTP by nearly Rs. 200, or about a quarter of the average WTP for

\footnotetext{
${ }^{10}$ We include a dummy variable for Seed 4 since selecting this seed implied inconsistent risk preferences.
} 
insurance. ${ }^{11}$ This could be due to increased liquidity, to an increase in trust in the insurance provider, or to an increase in the salience of risk, as farmers with payouts recently experienced a production shock.

Finally, Column (5) controls for several other household and farmer characteristics. Age matters: farmers are willing to pay more for insurance as they get older, but this effect gets weaker for very young or very old farmers. Having completed tertiary education (or higher) is also associated with a significantly higher WTP. Other variables do not seem to be strongly related to farmers' valuations, including socioeconomic ones (e.g., income, caste, landholdings size), risk salience and exposure (concern about wheat risk or having recently experienced damage), familiarity with smartphones, and distance to the weather station (a proxy for basis risk in WBI). Finally, observing a higher random price during the practice round induces the farmer to offer a lower price during the real round, though only weakly, indicating perhaps a slight discouragement effect. The random price observed during the main female decision maker practice round (not reported here) does not have a statistically significant effect on the WTP during the real round.

\subsection{Gender differences}

A large literature exists on gender differences around risk-aversion, with men generally found more risk-taking than women (see, for instance, Powell and Ansic, 1997; Croson and Gneezy, 2009; and Borghans et al., 2009; for a review see Eckel and Grossman, 2008). In a metaanalysis, Byrnes, Miller and Schafer (1999) split studies in terms of framing and age of respondents and confirm a gender gap across most of these categories. In addition to preferences, other factors may explain differential gender attitudes towards insurance. For instance, in Haryana and Punjab, few women from landowning households are directly involved in agricultural production, and men typically control the income from farming, which may reduce women's WTP relative to that of men. Alternatively, if agricultural weather shocks induce a differential reduction in female- or child-related household expenditures, women may value the benefits of insurance more than men do.

\footnotetext{
${ }^{11}$ Wealthier farmers and farmers who took out a loan in the previous season (indicative of better access to credit) are willing to pay nearly Rs. 300 more for insurance, suggesting liquidity constraints as another barrier to enroll.
} 
We therefore study whether we observe differential valuation for insurance between women and men. As mentioned above, during the WTP elicitation exercise practice rounds were conducted with both the male farmer and the main female decision maker in each household. Table 4 shows alternative ordinary least squares specifications to assess the presence of gender differences in WTP for the insurance products offered. Overall, we find no gender differences in WTP across all products in Column (1) or for any of the individual insurance products in Column (2). This is in line with the findings of Bageant and Barrett (2017), Clarke and Kumar (2016), Giné, Townsend and Vickery (2008), and Jensen, Mude and Barrett (2018), who find no increased propensity to purchase index-based insurance from female farmers. ${ }^{12}$ Moreover, in Columns (3) through (6), we find no effects when interacting the gender of the respondent with other potentially relevant characteristics, such as whether the female respondent was the wife (as opposed to the mother) of the farmer or in terms of the level of education, literacy, and experience with farming of the female respondent.

\subsection{Discussion}

Summarizing, farmers' demand for PBI is stronger than for WBI, and having to take pictures does not appear to be a major barrier to enroll in products that include PBI coverage. Second, farmers expect to receive higher payouts and more complete insurance from a product that includes PBI. Although their willingness to pay remains too low to market the product at commercial premiums, PBI improves demand significantly when offered at the subsidized rates that are currently applicable for commercial crops within the national crop insurance scheme.

Alternative channels to improve farmers' willingness to pay could be at least threefold. A first channel is the timing of marketing and enrollment. At the time of the experiment (four months before land preparation for wheat), risk in wheat production may not yet have been very salient, or farmers may have preferred waiting until after the Kharif harvest before deciding to purchase insurance for the next season. A second channel could be insurance education, particularly discussing with farmers their expectations of the product's payouts and how much the premium associated with that average payout would need to be for the product to be sustainable. This seems especially important for the bundled product, for which farmers expect

\footnotetext{
${ }^{12}$ Takahashi et al. (2014) find, however, a higher likelihood of purchasing index-based livestock insurance in Kenya by females.
} 
double the payouts but are not willing to pay double the premium. A final channel is to design premium collection in such a way that liquidity constraints do not depress demand, for instance by deferring premium payments until the end of the season, and/or by linking insurance with credit, with insurance premiums included in the loan repayments or deducted from the loan.

\section{Adverse selection}

While PBI may be regarded as an innovation to reduce basis risk in index insurance and improve demand, it departs from index products in an important way: insurance payouts depend directly on individual crop losses as opposed to other proxy measures. In this sense, PBI is closer to traditional indemnity products than to index products. As such, well-studied informationasymmetry problems in indemnity insurance markets such as moral hazard and adverse selection - problems that have been overcome by providing index insurance-return to the surface and threaten to become a concern. This final section addresses the issue of adverse selection, or the tendency for an insurance product to be purchased by riskier farmers (who value it the most, since they expect the highest payouts), potentially inducing insurance companies to raise premiums, crowding out less risky farmers and threatening the sustainability of the product.

We study two aspects of adverse selection: at the farmer level and at the plot level. For the former, we test whether farmers with worse yields and farmers for whom experts detected higher damage in crop pictures (arguably the riskier ones) are willing to pay relatively more for PBI insurance coverage. For the latter, we exploit the fact that farmers were requested to select one single acre among their wheat plots for which to get insurance, and test whether the selected plots exhibit riskier characteristics relative to the farmer's other plots.

\subsection{Farmer-level adverse selection}

Table 5 shows ordinary least squares estimates of farmers' WTP for the WBI only, PBI only, and $W B I+P B I$ products as a function of six variables capturing different elements of crop damage and yields, interpreted as proxies for farmer riskiness. Each cell in the table represents a separate specification, showing only the estimated coefficient for each alternative variable. In the presence of adverse selection, riskier farmers (those with lower yields or higher levels of damage) should be willing to pay more for insurance coverage than less risky ones. However, we do not observe a significantly higher willingness to pay among farmers with higher visible 
damage (as independently assessed by agronomic experts) or lower Rabi 2015-16 and 2016-17 yields for any of the three types of insurance coverage. ${ }^{13}$ Testing for differences in point estimates, Columns (4) and (5) indicate that in relation to the WBI only product, point estimates for insurance products that include PBI coverage are not systematically higher in the case of damage variables, or lower in the case of yield variables, meaning that PBI does not worsen the risk pool relative to existing index products.

The first five variables in Table 5 represent different measures of a farmer's yield or damage in the preceding season, which could potentially affect WTP through a behavioral mechanism known as salience effect or recency bias. If a farmer's recent losses were to affect his subjective probability of expected losses for the upcoming season, this could bias the WTP for insurance of farmers with higher levels of damage or lower levels of yield. To circumvent such bias, the last variable in Table 5 relies on farmers' self-reported expected yields under a normal year and, as such, should not be affected by behavioral biases related to recent events. As for the variables related to the preceding season, farmers reporting to expect lower yields also do not show a statistically significant higher WTP for insurance products, and the tests of differences in Columns (4) and (5) show no statistical differences for these coefficients between products. Combined, these findings indicate that additional PBI coverage does not raise the incidence of selection on a farmer's risk profile.

\subsection{Plot-level adverse selection}

Next, we explore the evidence for adverse selection at the plot level, by testing whether the plot that a farmer chooses to enroll into insurance is of lower quality or more prone to suffer damage than his remaining plots. To that end, we conduct both ordinary least squares (OLS) and household fixed effects panel regressions, treating a plot as the unit of observation, and using a dummy variable indicating whether a plot is selected to be enrolled in insurance as our independent variable. We regress a range of plot characteristics as the dependent variable against this dummy variable. Table 6 shows the results of this analysis, where each cell in the table corresponds to the coefficient of the dummy variable estimated through one separate regression per cell.

${ }^{13}$ The significant coefficient for Rabi 2015-16 self-reported yields for the PBI only WTP has the opposite sign to what would be implied by adverse selection: farmers with higher yields are willing to pay more for this insurance product. 
First, although the insurance product was meant to cover one single acre, farmers tend to enroll larger plots. This could be related to a plot needing to be large enough to fit in the full picture frame, to larger plots being the ones considered most important by the farmer, or simply due to misunderstanding of the insurance conditions. Second, farmers choose plots located closer to their home (though this variable is only significant in the household fixed effects panel regression), perhaps because they will need to visit that plot more often to take repeat pictures. Neither plot size nor distance to home are, however, characteristics that would normally imply a higher level of riskiness, and thus we do not take them as evidence of plot-level adverse selection. For variables potentially related to a plot's exposure to risks-such as how far the plot is from an irrigation source, previous year's yields, soil type, fertility and drainage, and sales and rental value-we find no statistically significant differences between selected and other plots. Moreover, the magnitude of the point estimates for these differences is small. This evidence allows us to conclude that in this sample, plot-level adverse selection does not occur.

\section{Conclusions}

Digital technologies such as smartphones and satellite remote sensing are promising tools to reduce information asymmetries in insurance markets and provide high-quality insurance to underserved populations that depend on agricultural incomes for their subsistence. For instance, by relying on pictures taken by farmers using inexpensive smartphone cameras, PBI can provide insurers with eyes on the ground to verify losses at minimal cost and monitor crop management. However, since PBI pays out according to a farmer's individual visible losses, and since insurers may not be able to observe an individual farmer's exposure to risk through the smartphone images, this digital technology may not be able to fully overcome traditional informationasymmetry issues from indemnity insurance. As a result, adverse selection may arise, which could in the long run increase premiums to unsustainable levels.

In this paper, we use willingness to pay elicited for different types of insurance products to analyze the demand for PBI and test for adverse selection. Overall, farmers are willing to pay more for PBI than for more traditional weather index-based products. This seems to be in line with farmers recognizing the basis risk-reducing benefits of PBI relative to WBI: farmer expectations of PBI payouts, especially during bad years, indicate that they believe this product can capture damage considerably better than the alternative WBI product. This conclusion is 
further supported by the negative effect of PBI on the correlation between risk aversion and the willingness to pay for weather index-based insurance, consistent with the idea that basis risk deters risk-averse farmers from taking up insurance. Moreover, the requirement of having to take pictures on a regular basis does not seem to be a major factor according to farmers' WTP, reinforcing the findings in Ceballos, Kramer, and Robles (2019) about the feasibility of this insurance approach. Finally, the digital technology does not appear to aggravate existing social gaps: the youth and elderly are willing to pay most, and WTP is not associated with income, caste, landholdings, risk salience and risk exposure, familiarity with smartphones, or gender.

While the WTP for these insurance products is still below the current commercial premiums for PBI, our findings indicate that this type of insurance product could be potentially offered within the PMFBY at levels closer to the 5 percent of the sum insured used for insurance for commercial crops, which could help reduce government subsidy levels. Moreover, once the insurance company incorporates data from the product's performance along a few seasons and gains experience with PBI value proposition for farmers, it is expected that premiums would be reduced to more sustainable levels, closer to farmers' actual WTP. Finally, solutions that help relax liquidity constraints (for instance, deferred premium payments or bundling with loans) and insurance education may help better align farmers' willingness to pay with insurance premiums.

We find no evidence for PBI inducing adverse selection. Using six alternative proxies of farmer riskiness, we do not find riskier farmers valuing either weather- or picture-based products differentially more. In addition, farmers do not seem to choose riskier plots for insurance, as captured through survey data on geographic and soil characteristics of a farmer's entire set of plots. Nevertheless, multiple factors might be at play in farmers' decisions around insurance, some of which may be inducing advantageous selection (less riskier farmers valuing insurance more), which could offset any adverse selection. Importantly, the increased valuation for PBI relative to WBI is not higher among riskier farmers. We take this as evidence that PBI, closer in nature to an indemnity product, does not seem to bring about adverse selection in a stronger way than existing index products. In addition, adverse selection may require some learning and thus become relevant once farmers have more experience with a given insurance product. This and other dynamic considerations remain as important research questions that will require longerterm studies. 
Finally, it is important to note that in unregulated insurance markets, adverse selection may conceptually be regarded as a positive development that is indicative of farmers making rational decisions and purchasing insurance only when it is welfare-enhancing given their personal circumstances. In voluntary insurance markets, adverse selection is an unavoidable consequence of the cost-benefit analysis implicit in a farmer's purchase decision. Riskier farmers may naturally value insurance coverage more and be willing to participate in the market at higher price levels. In this sense, our findings could indicate that farmers are not paying enough attention to their individual risk profiles or, given their risk profiles, to the expected benefits they would derive from insurance. For insurance interventions to be welfare-enhancing, a priority may be to strengthen farmers' awareness of the costs and benefits associated with insurance given their individual risk profiles, so that enrollment increases among farmers who would benefit from insurance the most. 
Tables and Figures

Table 1. Summary statistics

\begin{tabular}{|c|c|c|c|c|}
\hline & $\begin{array}{c}\text { (1) } \\
\text { Completed } \\
\text { baseline }\end{array}$ & $\begin{array}{c}(2) \\
\text { Not selected } \\
\text { for WTP (LA) }\end{array}$ & $\begin{array}{c}\text { (3) } \\
\text { Selected for } \\
\text { WTP (LA) }\end{array}$ & $\begin{array}{c}(4) \\
\text { Difference } \\
(2)-(1)\end{array}$ \\
\hline PBI village & $\begin{array}{c}0.503 \\
(0.071)\end{array}$ & $\begin{array}{c}0.503 \\
(0.073)\end{array}$ & $\begin{array}{c}0.500 \\
(0.115)\end{array}$ & $\begin{array}{l}-0.003 \\
(0.101)\end{array}$ \\
\hline Age (in years) & $\begin{array}{l}39.143 \\
(0.722)\end{array}$ & $\begin{array}{l}39.245 \\
(0.729)\end{array}$ & $\begin{array}{l}38.490 \\
(1.580)\end{array}$ & $\begin{array}{l}-0.755 \\
(1.507)\end{array}$ \\
\hline Completed tertiary education & $\begin{array}{c}0.438 \\
(0.019)\end{array}$ & $\begin{array}{c}0.426 \\
(0.020)\end{array}$ & $\begin{array}{c}0.510 \\
(0.053)\end{array}$ & $\begin{array}{c}0.084 \\
(0.057)\end{array}$ \\
\hline Belongs to sched./OB caste & $\begin{array}{c}0.102 \\
(0.029)\end{array}$ & $\begin{array}{c}0.112 \\
(0.031)\end{array}$ & $\begin{array}{c}0.040 \\
(0.031)\end{array}$ & $\begin{array}{l}-0.071 \\
(0.035)\end{array}$ \\
\hline Landholdings (hectares) & $\begin{array}{l}8.845 \\
(0.181)\end{array}$ & $\begin{array}{c}8.871 \\
(0.192)\end{array}$ & $\begin{array}{c}8.683 \\
(0.439)\end{array}$ & $\begin{array}{l}-0.189 \\
(0.460)\end{array}$ \\
\hline Household size & $\begin{array}{c}6.240 \\
(0.119)\end{array}$ & $\begin{array}{c}6.313 \\
(0.119)\end{array}$ & $\begin{array}{c}5.780 \\
(0.282)\end{array}$ & $\begin{array}{l}-0.533 * \\
(0.282)\end{array}$ \\
\hline Perception of yield variability & $\begin{array}{c}3.993 \\
(0.088)\end{array}$ & $\begin{array}{c}4.002 \\
(0.093)\end{array}$ & $\begin{array}{c}3.940 \\
(0.183)\end{array}$ & $\begin{array}{l}-0.062 \\
(0.190)\end{array}$ \\
\hline Share of income from crops & $\begin{array}{c}0.835 \\
(0.012)\end{array}$ & $\begin{array}{c}0.838 \\
(0.012)\end{array}$ & $\begin{array}{c}0.815 \\
(0.026)\end{array}$ & $\begin{array}{l}-0.023 \\
(0.022)\end{array}$ \\
\hline $\begin{array}{l}\text { Share of crop income from } \\
\text { wheat }\end{array}$ & $\begin{array}{c}0.376 \\
(0.010)\end{array}$ & $\begin{array}{c}0.373 \\
(0.010)\end{array}$ & $\begin{array}{c}0.392 \\
(0.018)\end{array}$ & $\begin{array}{c}0.019 \\
(0.016)\end{array}$ \\
\hline $\begin{array}{l}\text { Fraction of land planned to be } \\
\text { sown with wheat }\end{array}$ & $\begin{array}{c}0.961 \\
(0.007)\end{array}$ & $\begin{array}{c}0.960 \\
(0.008)\end{array}$ & $\begin{array}{c}0.967 \\
(0.012)\end{array}$ & $\begin{array}{c}0.006 \\
(0.014)\end{array}$ \\
\hline Wheat yield Rabi 2015/16 & $\begin{array}{l}19.570 \\
(0.156)\end{array}$ & $\begin{array}{l}19.579 \\
(0.159)\end{array}$ & $\begin{array}{l}19.516 \\
(0.315)\end{array}$ & $\begin{array}{l}-0.063 \\
(0.302)\end{array}$ \\
\hline Ever used laser land leveler & $\begin{array}{c}0.707 \\
(0.038)\end{array}$ & $\begin{array}{c}0.706 \\
(0.039)\end{array}$ & $\begin{array}{c}0.720 \\
(0.070)\end{array}$ & $\begin{array}{c}0.014 \\
(0.065)\end{array}$ \\
\hline $\begin{array}{l}\text { Distance from plot to home } \\
\text { (minutes) }\end{array}$ & $\begin{array}{l}15.900 \\
(1.186)\end{array}$ & $\begin{array}{l}15.640 \\
(1.072)\end{array}$ & $\begin{array}{l}17.459 \\
(3.126)\end{array}$ & $\begin{array}{c}1.819 \\
(2.760)\end{array}$ \\
\hline Owns insured plot & $\begin{array}{c}0.938 \\
(0.011)\end{array}$ & $\begin{array}{c}0.942 \\
(0.010)\end{array}$ & $\begin{array}{c}0.909 \\
(0.034)\end{array}$ & $\begin{array}{l}-0.033 \\
(0.034)\end{array}$ \\
\hline $\begin{array}{l}\text { Takes pictures on phone } \\
\text { often/very often }\end{array}$ & $\begin{array}{c}0.774 \\
(0.025)\end{array}$ & $\begin{array}{c}0.777 \\
(0.027)\end{array}$ & $\begin{array}{c}0.760 \\
(0.045)\end{array}$ & $\begin{array}{l}-0.017 \\
(0.048)\end{array}$ \\
\hline $\begin{array}{l}\text { Has network signal often/very } \\
\text { often }\end{array}$ & $\begin{array}{c}0.755 \\
(0.030) \\
\end{array}$ & $\begin{array}{c}0.761 \\
(0.029) \\
\end{array}$ & $\begin{array}{c}0.720 \\
(0.070) \\
\end{array}$ & $\begin{array}{c}-0.041 \\
(0.065) \\
\end{array}$ \\
\hline Number of farmers & 736 & 636 & 100 & \\
\hline
\end{tabular}

Note: This table shows the mean value of baseline farmer characteristics across different sub-groups of study farmers. Column 1 includes all farmers who completed a baseline interview, column 2 those farmers who were not selected for the WTP elicitation exercise, and column 3 those that were selected. Column 4 shows the results of tests of equality of means between these groups. Standard errors, clustered at the village level, are in parentheses. $* * *, * *$, and $*$ denote statistical significance at the 1,5 , and 10 percent level, respectively. 
Table 2. Perceptions around effectiveness of insurance products

\begin{tabular}{lccccc}
\hline \hline & $\begin{array}{c}(1) \\
\text { WBI } \\
\text { only }\end{array}$ & $\begin{array}{c}(2) \\
\text { PBI only }\end{array}$ & $\begin{array}{c}(3) \\
\text { WBI+PBI }\end{array}$ & $\begin{array}{c}(4) \\
\text { Difference } \\
(\mathbf{2})-(\mathbf{1})\end{array}$ & $\begin{array}{c}(5) \\
\text { Difference } \\
(\mathbf{3})-(\mathbf{1})\end{array}$ \\
\hline Probability of paying out if crop damage & 0.454 & 0.521 & 0.653 & $0.067^{* * *}$ & $0.199^{* * *}$ \\
& $(0.019)$ & $(0.022)$ & $(0.020)$ & $(0.014)$ & $(0.012)$ \\
Estimated payout if product pays out (in Rs.) & 5,475 & 6,216 & 8,121 & $741^{* * *}$ & $2,646^{* * *}$ \\
& $(366)$ & $(393)$ & $(429)$ & $(160)$ & $(263)$ \\
Expected payout if crop damage (in Rs.) & 3,106 & 3,917 & 6,017 & $811^{* * *}$ & $2,911^{* * *}$ \\
& $(334)$ & $(384)$ & $(458)$ & $(187)$ & $(306)$ \\
\hline Notes: This table shows farmers' self-reported perceptions around the effectiveness of alternative insurance products \\
when suffering crop damage, in terms of the product's average probability of paying out, its average estimated payout \\
when it pays out, and the overall expected payout. The overall expected payout is calculated as the probability of paying \\
out times the estimated payout when it does. Columns 4 and 5 show the results of tests of equality of means between \\
these groups. Standard errors, clustered at the village level, are in parentheses. ***, **, and * denote statistical \\
significance at the 1, 5, and 10 percent level, respectively.
\end{tabular}


Table 3. Determinants of farmers' willingness to pay for insurance

\begin{tabular}{|c|c|c|c|c|c|}
\hline & \multicolumn{5}{|c|}{ Dependent variable: Willingness to pay for insurance (in Rs.) } \\
\hline & (1) & (2) & (3) & (4) & (5) \\
\hline WBI+Pics & $\begin{array}{l}-21.000 \\
(26.056)\end{array}$ & $\begin{array}{l}-21.000 \\
(26.090)\end{array}$ & $\begin{array}{l}-21.000 \\
(26.192)\end{array}$ & $\begin{array}{l}-13.750 \\
(28.427)\end{array}$ & $\begin{array}{l}-21.000 \\
(26.613)\end{array}$ \\
\hline PBI only & $\begin{array}{l}130.000 * * * \\
(19.723)\end{array}$ & $\begin{array}{c}130.000 * * * \\
(19.748)\end{array}$ & $\begin{array}{c}130.000 * * * \\
(19.826)\end{array}$ & $\begin{array}{l}96.250 * * * \\
(23.863)\end{array}$ & $\begin{array}{l}130.000^{* * *} \\
(20.145)\end{array}$ \\
\hline $\mathrm{WBI}+\mathrm{PBI}$ & $\begin{array}{l}316.000 * * * \\
(30.433)\end{array}$ & $\begin{array}{c}316.000 * * * \\
(30.473)\end{array}$ & $\begin{array}{l}316.000 * * * \\
(30.592)\end{array}$ & $\begin{array}{c}293.750 * * * \\
(40.834)\end{array}$ & $\begin{array}{l}316.000 * * * \\
(31.084)\end{array}$ \\
\hline PBI Treatment & & $\begin{array}{c}-231.944 * * * \\
(80.494)\end{array}$ & $\begin{array}{c}-229.400 * * * \\
(76.377)\end{array}$ & $\begin{array}{l}-229.400 * * * \\
(76.678)\end{array}$ & $\begin{array}{l}-233.104 * * \\
(90.395)\end{array}$ \\
\hline Risk Aversion & & & $\begin{array}{c}-164.579^{*} \\
(85.596)\end{array}$ & $\begin{array}{l}-184.891 * * \\
(75.657)\end{array}$ & $\begin{array}{l}-184.055 \\
(107.099)\end{array}$ \\
\hline Risk Aversion * WBI+Pics & & & & $\begin{array}{l}-12.083 \\
(33.081)\end{array}$ & \\
\hline Risk Aversion * PBI only & & & & $\begin{array}{l}56.250^{*} \\
(30.068)\end{array}$ & \\
\hline Risk Aversion * WBI+PBI & & & & $\begin{array}{c}37.083 \\
(48.673)\end{array}$ & \\
\hline Insurance Payout & & & $\begin{array}{c}197.067 * * \\
(91.373)\end{array}$ & $\begin{array}{l}197.067 * * \\
(91.734)\end{array}$ & $\begin{array}{l}146.809 \\
(92.838)\end{array}$ \\
\hline $\begin{array}{l}\text { Scheduled or Other Backward } \\
\text { Caste }\end{array}$ & & & & & $\begin{array}{l}103.446 \\
(312.262)\end{array}$ \\
\hline Total Area & & & & & $\begin{array}{l}-13.511 \\
(11.697)\end{array}$ \\
\hline Demeaned Age & & & & & $\begin{array}{c}9.422 * * \\
(4.281)\end{array}$ \\
\hline Age Squared & & & & & $\begin{array}{c}-0.477 * * \\
(0.212)\end{array}$ \\
\hline Tertiary Education & & & & & $\begin{array}{l}147.340^{*} \\
(71.163)\end{array}$ \\
\hline $\begin{array}{l}\text { Familiar Taking Smartphone } \\
\text { Pictures }\end{array}$ & & & & & $\begin{array}{c}29.167 \\
(113.659)\end{array}$ \\
\hline Has Kisan Card (KCC) & & & & & $\begin{array}{l}-1.555 \\
(88.302)\end{array}$ \\
\hline $\begin{array}{l}\text { Has Crop Insurance through } \\
\text { KCC }\end{array}$ & & & & & $\begin{array}{l}-65.385 \\
(166.445)\end{array}$ \\
\hline Wheat Risk Is Main Concern & & & & & $\begin{array}{c}489.168 \\
(612.015)\end{array}$ \\
\hline $\begin{array}{l}\text { Experienced Wheat Damage } \\
\text { Last Season }\end{array}$ & & & & & $\begin{array}{l}137.505 \\
(157.548)\end{array}$ \\
\hline $\begin{array}{l}\text { Above Median Distance to } \\
\text { Weather Station }\end{array}$ & & & & & $\begin{array}{c}136.430 \\
(188.624)\end{array}$ \\
\hline $\begin{array}{l}\text { Price of Product in Male } \\
\text { Practice Round }\end{array}$ & & & & & $\begin{array}{l}-0.065^{*} \\
(0.037) \\
\end{array}$ \\
\hline Number of observations & 400 & 400 & 400 & 400 & 400 \\
\hline R-squared & 0.329 & 0.377 & 0.415 & 0.415 & 0.472 \\
\hline Mean of dependent variable & 842.3 & 842.3 & 842.3 & 842.3 & 842.3 \\
\hline
\end{tabular}




\section{Table 4. Gender differences in willingness to pay during practice round}

\begin{tabular}{|c|c|c|c|c|c|c|}
\hline & (1) & (2) & (3) & (4) & (5) & (6) \\
\hline & & & Willingness & Pay (in Rs.) & & \\
\hline Female respondent & $\begin{array}{c}-40.593 \\
(50.029)\end{array}$ & & $\begin{array}{c}-11.667 \\
(78.666)\end{array}$ & $\begin{array}{c}-72.569 \\
(101.015)\end{array}$ & $\begin{array}{c}-65.682 \\
(73.284)\end{array}$ & $\begin{array}{l}-25.735 \\
(80.301)\end{array}$ \\
\hline WBI only & & $\begin{array}{c}435.889 * * * \\
(30.189)\end{array}$ & & & & \\
\hline WBI + Pictures & & $\begin{array}{c}362.693 * * * \\
(23.546)\end{array}$ & & & & \\
\hline PBI only & & $\begin{array}{c}574.034 * * * \\
(39.523)\end{array}$ & & & & \\
\hline $\mathrm{WBI}+\mathrm{PBI}$ & & $\begin{array}{c}808.570^{* * * *} \\
(33.458)\end{array}$ & & & & \\
\hline WBI only * Female respondent & & $\begin{array}{l}-42.784 \\
(51.075)\end{array}$ & & & & \\
\hline WBI + Pictures * Female respondent & & $\begin{array}{c}-5.155 \\
(46.201)\end{array}$ & & & & \\
\hline PBI only * Female respondent & & $\begin{array}{c}-62.887 \\
(52.527)\end{array}$ & & & & \\
\hline $\mathrm{WBI}+\mathrm{PBI} *$ Female respondent & & $\begin{array}{l}-51.546 \\
(58.567)\end{array}$ & & & & \\
\hline Female respondent is wife of farmer & & & $\begin{array}{c}-53.958 \\
(112.268)\end{array}$ & & & \\
\hline Female respondent has completed primary & & & & $\begin{array}{c}50.848 \\
(116.776)\end{array}$ & & \\
\hline Female respondent can read and write & & & & & $\begin{array}{c}57.944 \\
(93.704)\end{array}$ & \\
\hline Female respondent has farming experience & & & & & & $\begin{array}{c}-31.330 \\
(87.729)\end{array}$ \\
\hline Observations & 776 & 776 & 776 & 776 & 776 & 776 \\
\hline R-squared & 0.525 & 0.919 & 0.526 & 0.526 & 0.526 & 0.525 \\
\hline Mean of dependent variable & 738.388 & 738.388 & 738.388 & 738.388 & 738.388 & 738.388 \\
\hline
\end{tabular}

Note: This table shows ordinary least squares estimates of male and female farmer WTP for insurance during a practice round, as a function of the gender of the respondent, the type of insurance product offered, and a number of characteristics of the female respondent. A constant and household fixed effects are included but not reported. Robust standard errors, clustered at the village level, are in parentheses. ***, **, and * denote statistical significance at the 1,5 , and 10 percent level, respectively. 
Table 5. Willingness to pay for insurance and farmer riskiness

\begin{tabular}{|c|c|c|c|c|c|c|}
\hline \multirow[b]{2}{*}{ Variable } & \multicolumn{3}{|c|}{ WTP for: } & \multicolumn{2}{|c|}{ Test of differences: } & \multirow{2}{*}{$\begin{array}{l}\text { Num. } \\
\text { of obs. }\end{array}$} \\
\hline & $\begin{array}{c}\text { (1) } \\
\text { WBI only }\end{array}$ & $\begin{array}{c}(2) \\
\text { PBI only }\end{array}$ & $\begin{array}{c}(3) \\
\text { WBI+PBI }\end{array}$ & (2) - (1) & (3) - (1) & \\
\hline $\begin{array}{l}\text { Damage due to } \\
\text { mismanagement }\end{array}$ & $\begin{array}{c}20.848 \\
(19.594)\end{array}$ & $\begin{array}{l}23.748 \\
(22.613)\end{array}$ & $\begin{array}{l}30.053 \\
(25.824)\end{array}$ & $\begin{array}{c}2.900 \\
(9.011)\end{array}$ & $\begin{array}{c}9.204 \\
(12.167)\end{array}$ & 97 \\
\hline $\begin{array}{l}\text { Damage not due to } \\
\text { mismanagement }\end{array}$ & $\begin{array}{l}-0.241 \\
(3.959)\end{array}$ & $\begin{array}{l}-2.514 \\
(4.560)\end{array}$ & $\begin{array}{l}-0.860 \\
(5.224)\end{array}$ & $\begin{array}{l}-2.273 \\
(1.793)\end{array}$ & $\begin{array}{l}-0.619 \\
(2.450)\end{array}$ & 97 \\
\hline Total damage & $\begin{array}{c}1.582 \\
(3.984)\end{array}$ & $\begin{array}{l}-0.602 \\
(4.601)\end{array}$ & $\begin{array}{c}1.456 \\
(5.260)\end{array}$ & $\begin{array}{l}-2.184 \\
(1.808)\end{array}$ & $\begin{array}{l}-0.126 \\
(2.468)\end{array}$ & 97 \\
\hline $\begin{array}{l}\text { Rabi 2016-17 crop cutting } \\
\text { yield }\end{array}$ & $\begin{array}{c}-5.041 \\
(13.687)\end{array}$ & $\begin{array}{c}0.225 \\
(16.016)\end{array}$ & $\begin{array}{c}13.907 \\
(18.359)\end{array}$ & $\begin{array}{c}5.267 \\
(6.292)\end{array}$ & $\begin{array}{c}18.948 * * \\
(8.388)\end{array}$ & 94 \\
\hline $\begin{array}{l}\text { Rabi } 2015-16 \text { self-reported } \\
\quad \text { yield }\end{array}$ & $\begin{array}{l}36.500 \\
(22.411)\end{array}$ & $\begin{array}{l}44.266^{*} \\
(26.182)\end{array}$ & $\begin{array}{c}47.561 \\
(29.805)\end{array}$ & $\begin{array}{c}7.766 \\
(10.115)\end{array}$ & $\begin{array}{c}11.061 \\
(13.742)\end{array}$ & 100 \\
\hline $\begin{array}{l}\text { Expected yield during } \\
\text { normal year }\end{array}$ & $\begin{array}{c}1.033 \\
(23.895)\end{array}$ & $\begin{array}{c}13.296 \\
(27.912)\end{array}$ & $\begin{array}{c}11.042 \\
(31.738)\end{array}$ & $\begin{array}{c}12.263 \\
(10.581)\end{array}$ & $\begin{array}{c}10.009 \\
(14.449)\end{array}$ & 100 \\
\hline Mean of dependent variable & 736 & 866 & 1,052 & 130 & 316 & \\
\hline
\end{tabular}


Table 6. Characteristics of plot selected for insurance

\begin{tabular}{|c|c|c|c|c|c|}
\hline Variable & OLS & $\begin{array}{c}\text { Household } \\
\text { Fixed } \\
\text { Effects } \\
\end{array}$ & $\begin{array}{c}\text { Mean of } \\
\text { dep. } \\
\text { var. }\end{array}$ & $\begin{array}{l}\text { Num. of } \\
\text { Obs. }\end{array}$ & $\begin{array}{l}\text { Num. of } \\
\text { HHs }\end{array}$ \\
\hline Area (acres) & $\begin{array}{c}0.995 * * * \\
(0.324)\end{array}$ & $\begin{array}{c}0.838 * * * \\
(0.315)\end{array}$ & 3.198 & 230 & 97 \\
\hline Distance to home (mins. walking) & $\begin{array}{l}-1.019 \\
(1.518)\end{array}$ & $\begin{array}{l}-2.964 * * \\
(1.413)\end{array}$ & 19.510 & 184 & 92 \\
\hline $\begin{array}{l}\text { Distance to irrigation (mins. } \\
\text { walking) }\end{array}$ & $\begin{array}{l}-0.462 \\
(0.329)\end{array}$ & $\begin{array}{l}-0.109 \\
(0.162)\end{array}$ & 3.019 & 172 & 86 \\
\hline $\begin{array}{l}\text { Yield in Rabi 2015/16 (quintals } \\
\text { per acre) }\end{array}$ & $\begin{array}{l}-0.047 \\
(0.315)\end{array}$ & $\begin{array}{c}0.032 \\
(0.315)\end{array}$ & 19.330 & 214 & 94 \\
\hline Sandy loam soil & $\begin{array}{l}-0.037 \\
(0.043)\end{array}$ & $\begin{array}{l}-0.012 \\
(0.034)\end{array}$ & 0.619 & 184 & 92 \\
\hline $\begin{array}{l}\text { Soil has Good or Very Good } \\
\text { fertility }\end{array}$ & $\begin{array}{c}0.008 \\
(0.019)\end{array}$ & $\begin{array}{c}0.012 \\
(0.020)\end{array}$ & 0.981 & 184 & 92 \\
\hline Less fertile than other plots & $\begin{array}{l}-0.020 \\
(0.014)\end{array}$ & $\begin{array}{l}-0.024 \\
(0.016)\end{array}$ & 0.019 & 184 & 92 \\
\hline Soil has good drainage & $\begin{array}{c}0.004 \\
(0.029)\end{array}$ & $\begin{array}{c}0.012 \\
(0.030)\end{array}$ & 0.962 & 184 & 92 \\
\hline Worse drainage than other plots & $\begin{array}{l}-0.026 \\
(0.028)\end{array}$ & $\begin{array}{l}-0.036 \\
(0.030)\end{array}$ & 0.048 & 184 & 92 \\
\hline Sales value (lakh Rs. per acre) & $\begin{array}{c}0.150 \\
(0.655)\end{array}$ & $\begin{array}{c}0.099 \\
(0.299)\end{array}$ & 23.190 & 230 & 97 \\
\hline $\begin{array}{l}\text { Rental value (thousand Rs. per } \\
\text { acre per year) }\end{array}$ & $\begin{array}{c}0.714 \\
(0.573)\end{array}$ & $\begin{array}{l}-0.138 \\
(0.157)\end{array}$ & 38.690 & 230 & 97 \\
\hline
\end{tabular}

Note: This table shows the results from ordinary least squares (OLS, column 1) and panel household-level fixed effects (column 2) specifications using a number of soil characteristics as the dependent variable against a dummy variable indicating whether a plot has been selected for insurance. Each cell shows the estimated coefficient for this dummy variable. A constant is included but not reported. Standard errors, clustered at the household level, are in parentheses. ${ }^{* *},{ }^{* *}$, and $*$ denote statistical significance at the 1,5 , and 10 percent levels, respectively. 
Figure 1 - Scratch card to elicit willingness to pay

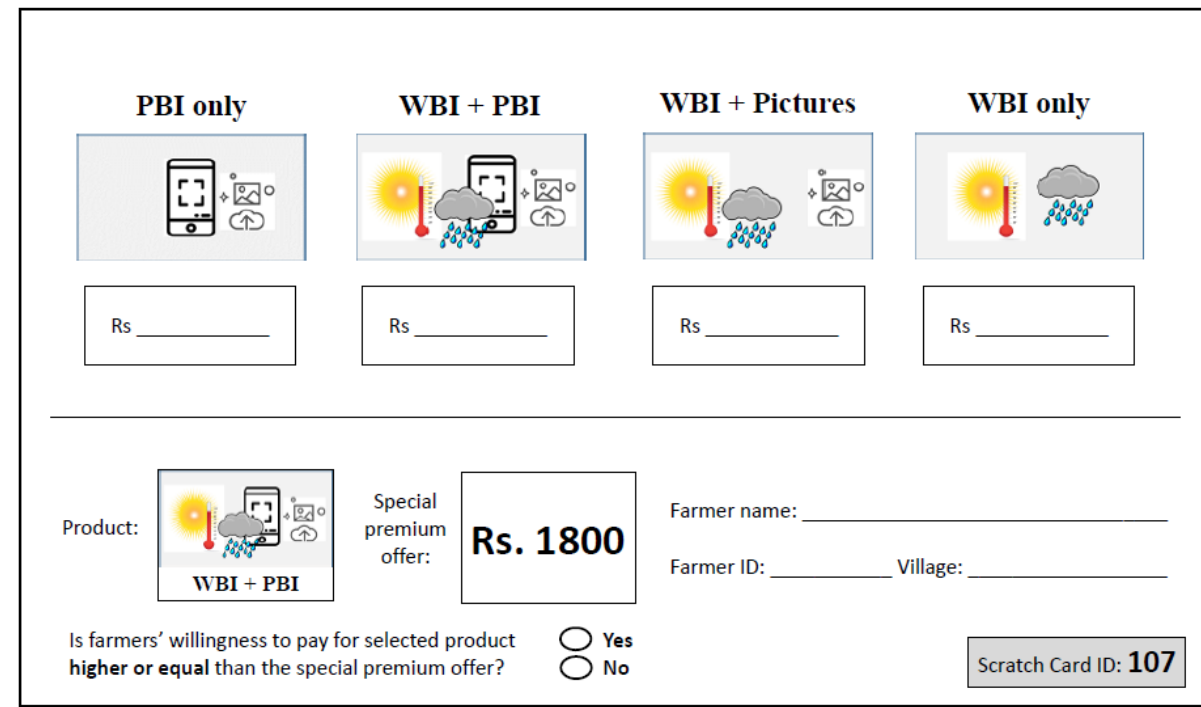

Notes: This figure shows an example of a scratch card used to elicit willingness to pay in the field. The top half of the card shows pictorially the four alternative products for which farmers were being requested to state their maximum WTP, the order of which was random across cards. The bottom half of the card includes two boxes that contained a randomly-selected product and special premium offer and were covered with metallic scratch-off ink.

Figure 2 - Average willingness to pay by product

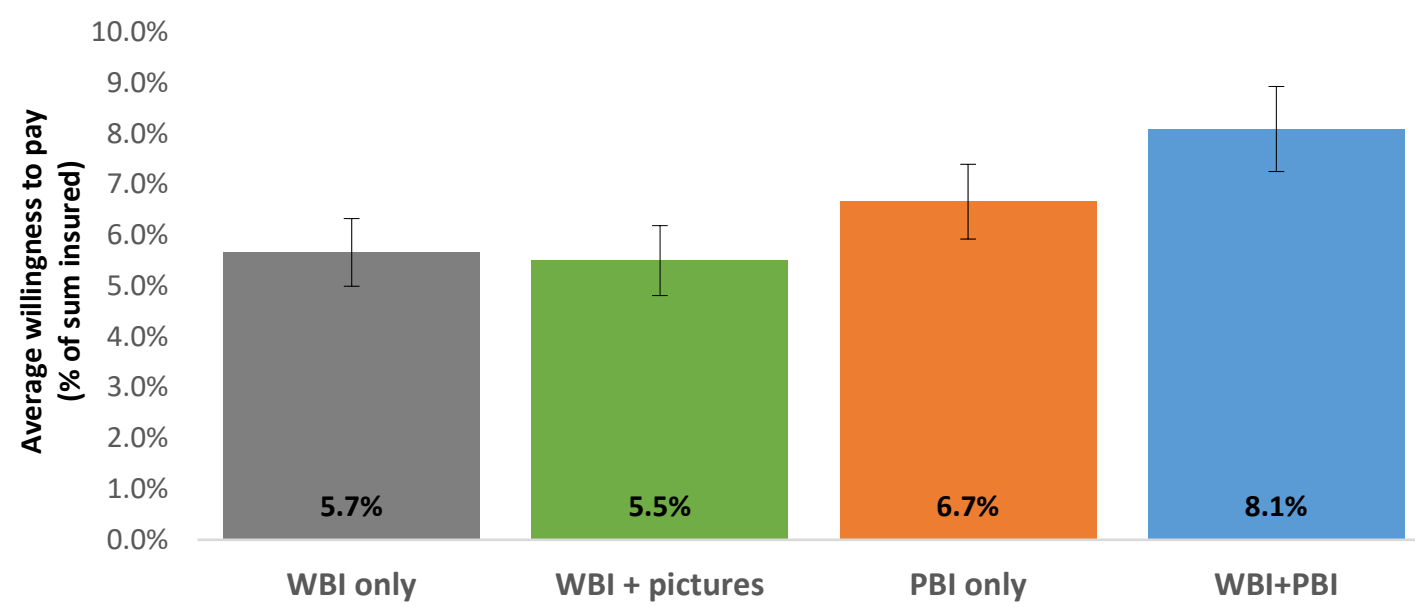

Notes: This figure shows the average willingness to pay, as a percentage of the sum insured, for four alternative insurance products offered to farmers. Confidence intervals at the 95 percent level are shown for each bar. 
Figure 3 - Demand curves by product

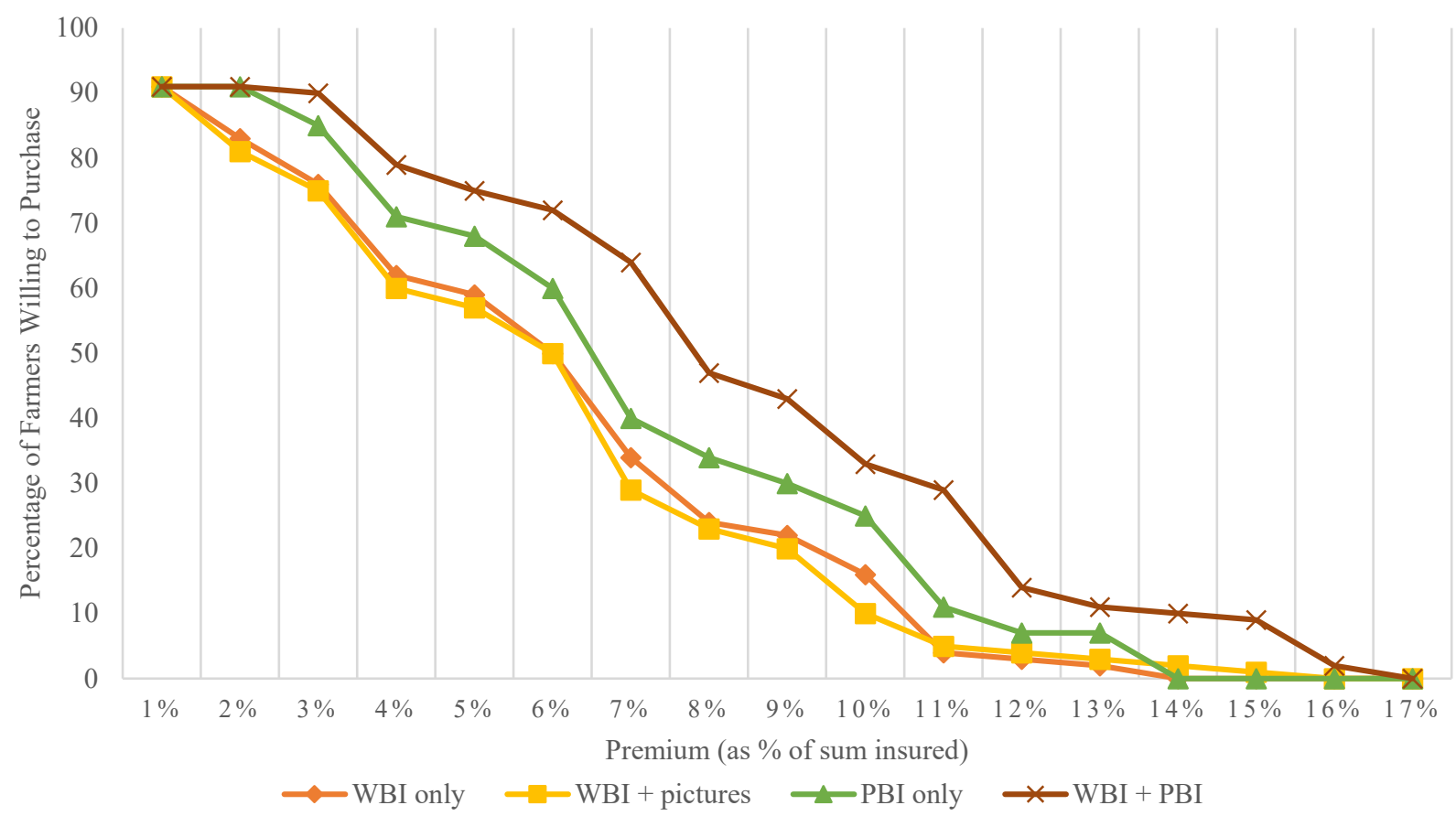

Notes: This figure shows demand curves for four alternative insurance products offered to farmers. The curves are constructed from individual farmer WTP for each product and show the percentage of farmers willing to purchase the product at each hypothetical premium. 


\section{References}

Akerlof, G. (1970). “The Market for 'Lemons': Quality Uncertainty and the Market Mechanism", Quarterly Journal of Economics, 84(3), pp. 488-500.

Bageant, E.R. and C.B. Barrett (2017). "Are There Gender Differences in Demand for IndexBased Livestock Insurance?” Journal of Development Studies 53(6): pp. 932-952.

Banerjee, A., E. Duflo and R. Hornbeck (2014). "Bundling health insurance and microfinance in India: There cannot be adverse selection if there is no demand," American Economic Review, 104(5), pp. 291-97.

Barrett, C. and J. McPeak (2006). "Poverty Traps and Safety Nets," in Poverty, Inequality and Development: Essays in Honor of Erik Thorbecke, edited by A. de Janvry and R. Kanbur, 131-154. New York: Springer.

Becker, G.M., M.H. Degroot and J. Marschak (1964). "Measuring Utility by a Single-Response Sequential Method," Systems Research and Behavioral Science 9(3): pp. 226-232.

Belissa, T., Bulte, E., Cecchi, F., Gangopadhyay, S. and Lensink, R. (2019). "Liquidity constraints, informal institutions, and the adoption of weather insurance: A randomized controlled trial in Ethiopia," Journal of Development Economics, 140, pp. 269-278.

Borghans, L., J.J. Heckman, B.H. Golsteyn and H. Meijers (2009). "Gender Differences in Risk Aversion and Ambiguity Aversion," Journal of the European Economic Association 7(2-3): pp. 649-658.

Bryan, G., D. Karlan and S. Nelson (2010). "Commitment Devices," Annual Review of Economics 2: pp. 671-698.

Byrnes, J.P., D.C. Miller and W.D. Schafer (1999). "Gender Differences in Risk Taking: A Meta-Analysis," Psychological Bulletin 125(3): p. 367.

Cariappa, A.G., G.B. Lokesh and G.B. Ramesh (2017). "Progress of Crop Insurance and Pradhan Mantri Fasal Bima Yojana in India," Agricultural Economics Research Review 30.

Ceballos, F. and B. Kramer (2019). "Big Brother Might be Watching You: Testing for Moral Hazard in Picture-Based Crop Insurance", mimeo. 
Ceballos, F., B. Kramer and M. Robles (2019). "The Feasibility of Picture-Based Insurance (PBI): Smartphone Pictures for Affordable Crop Insurance," Development Engineering 4, 100042.

Chiappori, P.A. and Salanié, B. (2000). "Testing for asymmetric information in insurance markets," Journal of Political Economy, 108(1), pp. 56-78.

Clarke, D.J. (2016). “A Theory of Rational Demand for Index Insurance," American Economic Journal: Microeconomics 8(1): pp. 283-306.

Clarke, D.J. and M. Kalani (2011). "Microinsurance Decisions: Evidence from Ethiopia," mimeo, Oxford University.

Clarke, D.J. and N. Kumar (2016). "Microinsurance Decisions: Gendered Evidence from Rural Bangladesh," Gender, Technology and Development 20(2): pp. 218-241.

Clarke, D., O. Mahul, K.N. Rao and N. Verma (2012). "Weather-Based Crop Insurance in India," World Bank Policy Research Working Paper 5985, Washington, DC.

Cohen, A. and P. Siegelman (2010). "Testing for Adverse Selection in Insurance Markets," Journal of Risk and insurance 77(1): pp. 39-84.

Cole, S., X. Giné, J. Tobacman, P.B. Topalova, R.M. Townsend and J.I. Vickery (2013). "Barriers to Household Risk Management: Evidence from India," American Economic Journal: Applied Economics 5(1): pp. 104-135.

Cole, S., X. Giné and J. Vickery (2017). "How Does Risk Management Influence Production Decisions? Evidence from a Field Experiment," Review of Financial Studies 30(6): pp. 19351970.

Cole, S., D. Stein and J. Tobacman (2014). "Dynamics of Demand for Index Insurance: Evidence from a Long-Run Field Experiment," American Economic Review 104(5): pp. 284-90.

Cole, S., D. Stein and J. Tobacman (2011). "What Is Rainfall Index Insurance Worth? A Comparison of Valuation Techniques," mimeo.

Croson, R. and U. Gneezy (2009). "Gender Differences in Preferences," Journal of Economic Literature 47(2): pp. 448-74.

Dercon, S. and J. Hoddinott (2004). "Health, Shocks, and Poverty Persistence," in Insurance against Poverty, edited by S. Dercon, 123-136. Oxford, UK: Oxford University Press 
Eckel, C.C. and P.J. Grossman (2008). "Men, Women and Risk Aversion: Experimental Evidence," Handbook of Experimental Economics Results 1: pp. 1061-1073.

Giné, X., Goldberg, J., Silverman, D. and Yang, D. (2018). "Revising Commitments: Field Evidence on the Adjustment of Prior Choices," Economic Journal, 128(608), pp.159-188.

Giné, X., R. Townsend and J. Vickery (2008). "Patterns of Rainfall Insurance Participation in Rural India," World Bank Economic Review 22(3): pp. 539-566.

Hazell, P., C. Pomareda and A. Valdes (1986). "Crop Insurance for Agricultural Development”. Baltimore: Johns Hopkins University Press.

He, J., R.M. Rejesus, X. Zheng and J.M. Yorobe Jr (2018). "Advantageous Selection in Crop Insurance: Theory and Evidence," Journal of Agricultural Economics, 69(3), pp. 646-668.

He, J., X. Zheng, R.M. Rejesus and J.M. Yorobe Jr (2017). "Moral Hazard and Adverse Selection Effects of Cost-of-Production Crop Insurance with Input Monitoring: Evidence from the Philippines," mimeo.

Hill, R., J. Hoddinott and N. Kumar (2013). "Adoption of Weather-Index Insurance: Learning from Willingness to Pay among a Panel of Households in Rural Ethiopia." Agricultural Economics, 44(4-5): pp. 385-398.

Hill, R.V., M. Robles and F. Ceballos (2016). "Demand for a Simple Weather Insurance Product in India: Theory and Evidence," American Journal of Agricultural Economics 98(4): pp. $1250-1270$.

Janssens, W., Kramer, B. and Swart, L. (2017). "Be patient when measuring hyperbolic discounting: Stationarity, time consistency and time invariance in a field experiment," Journal of Development Economics, 126, pp.77-90.

Jensen, N.D., A.G. Mude and C.B. Barrett (2018). "How Basis Risk and Spatiotemporal Adverse Selection Influence Demand for Index Insurance: Evidence from Northern Kenya," Food Policy 74: pp. 172-198.

Just, R.E., L. Calvin and J. Quiggin (1999). "Adverse Selection in Crop Insurance: Actuarial and Asymmetric Information Incentives," American Journal of Agricultural Economics 81(4): pp. 834-849. 
Karlan, D., R. Osei, I. Osei-Akoto and C. Udry (2014). “Agricultural Decisions after Relaxing Credit and Risk Constraints," Quarterly Journal of Economics 129(2): pp. 597-652.

Makki, S. and A. Somwaru (2001). "Evidence of Adverse Selection in Crop Insurance Markets," Journal of Risk and Insurance 68(4): pp. 685-708.

Matul, M., A. Dalal, O. De Bock and W. Gelade (2013). "Why People Do Not Buy Microinsurance and What We Can Do About It," Microinsurance Innovation Facility Briefing Note 17, Geneva.

Polemini, R. and D. Levine (2012). "Prices Matter: Comparing Two Tests of Adverse Selection in Health Insurance" Working Paper 135-12, Institute for Research on Labor and Employment, UC Berkeley, December 2012.

Powell, M. and D. Ansic (1997). “Gender Differences in Risk Behaviour in Financial DecisionMaking: An Experimental Analysis," Journal of Economic Psychology 18(6): pp. 605-628.

Stein, D (2011). "Paying Premiums with the Insurer's Money: How Loss Aversion Drives Dynamic Insurance Decisions," mimeo.

Stein, D. and J. Tobacman (2016). "Weather Insurance Savings Accounts," Geneva Papers on Risk and Insurance-Issues and Practice 41(4): pp. 677-700.

Takahashi, K., M. Ikegami, M. Sheahan and C.B. Barrett (2014). "Unpacking Factors Behind the (Low) Uptake of Index-Based Insurance: Quasi-experimental Evidence from Livestock Insurance in Southern Ethiopia," mimeo. 


\title{
Appendix A. Willingness to Pay Elicitation Script
}

\author{
READ EXACTLY FROM SCRIPT. DO NOT SAY ANYTHING THAT IS NOT IN SCRIPT.
}

Last Rabi 2016/17 season, BISA gave your household an insurance product for wheat. This insurance product was issued by HDFC Ergo, an insurance company. BISA paid HDFC for this insurance product in full. So last year, BISA paid the entire insurance premium for you.

This year, if you are interested in having insurance again, BISA is offering to still pay HDFC some of the premium for you; but you will also pay some of the premium yourself. How much you will have to pay depends on a special promotion, printed on a scratch card like this.

There is a random price printed on all scratch cards, just like when shops have special promotions; so the exact price you will have to pay depends on luck. Do you understand this?

\section{Practice round}

Here is how the promotion works: On this scratch card, we have 4 different insurance products. Each product covers one acre of wheat. The four products are the following .... [Explain briefly, from left to right]

- For each of these 4 products, you write down the maximum price (in rupees) that you are willing to pay for the product. So for each product, you should write down what you are willing to pay at most for that product; at any higher price, you would not be willing to purchase it; and at any lower price, you would be willing to purchase it. If there is an insurance product that you would not want to purchase at any price, you write down zero.

- Next, you scratch open these two grey boxes:

(1) The left box, "Product", will show which product you can purchase at the discounted price. You can purchase the other products later in the year, but only at the full price, not at the discounted price.

(2) The right box, "Special premium offer", will show the discounted price at which you can purchase that product. This can be anywhere between Rs. 200 and Rs. 4,000.

- Now, we look at your maximum price for the selected product, and the special premium offer. If your maximum price was higher than the special premium offer, you will buy the product, and you will only have to pay special premium offer. If your bid is lower than the special premium offer, then you cannot buy insurance at a discounted price. You will still have the choice to purchase any of the 4 insurance products at the full price later in the year.

BISA is paying the difference between the full price and the special premium offer. Your household can pay HDFC for your share, the special premium offer, by check. To save time, we will ask the person whose name will be on the insurance policy to write this check for HDFC already today. HDFC will not collect the money until October 31. So your maximum price should not be more than what you think your household can pay on October 31 st. We will of course send a reminder before the premium is collected. Is this clear?

The special premium offer is valid for one acre of land, and you will tell us which of your plots you would like to insure. The land needs to be in the name of the person who is insured. To verify that this is indeed the case, HDFC may ask for land papers before making insurance payouts. This is Indian regulation that HDFC has to comply with. So for the special premium offer, please choose a plot that is in the name of the person to be insured. Ok?

We will practice this with both of you separately, because this is important for the research. After that, we will do another round for real, with both of you together. Now, in this practice round, you can tell us what *you* really want - not what you think the others would want you to say. We will not tell anyone, also not in the round with the real card, what you choose in the practice round. So think very carefully about what you would be willing and able to pay. Ok? 
[Let respondent pick a card, then please enter Practice Card ID and re-enter the same Card ID. MAKE SURE THE IDS ENTERED ARE CORRECT BEFORE CONTINUING, YOU WILL NOT BE ABLE TO RETURN TO THIS SCREEN. THEN YOU WILL SEE THE QUESTION: "ARE YOU SURE YOU ARE HOLDING THE CARD WITH ID \# ...? THIS IS YOUR LAST CHANCE TO GO BACK AND CORRECT.”]

Which product is on the left-most side of the card? $\quad \square$ WBI only $\square$ PBI only

MOVING FROM LEFT TO RIGHT, REPEAT THE FOLLOWING:

You will now decide how much to pay for ... (name product) [Summarize the product using the brochure.] Now that you know more about this product, please think carefully, and tell me: What is the maximum amount that you would be willing to pay for this product? Rs. [Do not yet write down on the scratch card.]

You chose .... (X) as your maximum price.

- So, if your special premium offer turns out to be ... $(X+200)$, you will not be able to purchase ... at the special premium offer; only at the full market price, later in the year. Are you sure about this? $\square$ Yes $\square$ No (update amount)

- Or, if you scratch a special premium offer of ... (X) or less, then we will ask you to write a check for this amount, and HDFC will collect this money by October 31. Are you sure about this? $\square$ Yes $\square$ No (update amount)

Ok. Now that you are sure about your maximum price, please write it down on the card.

KEEP REPEATING THIS UNTIL THE RESPONDENT HAS WRITTEN THE MAX PRICE FOR ALL 4 PRODUCTS ON THE CARD.

In a few moments (not right now) I will ask you to scratch off the grey boxes. But remember: If the maximum amount you said you would be willing to pay for that product is at or above this discounted price, then you will get the product at the special discounted price. If your maximum amount is lower than the price, you will not get the product. Even if you are actually willing to buy it at that price, you will not be able to buy it at that price; you cannot change anything after you scratch the boxes.

[Record the maximum price entered for WBI + PBI. This amount is used in the test questions, amount $\mathrm{X}$ ]

\section{Test questions:}

Now, before you scratch off the practice boxes, we would like to ask you some questions to make sure that this is clear. If the product under the box is "WBI+PBI" ...

- $\quad$... will you be able to purchase "WBI only" at the special premium offer? $\square$ Yes (explain again that respondent cannot use the special premium offer for other products than the selected one) $\square$ No

- $\quad \ldots$ and the special premium offer is X-500, then how much will you pay to purchase "WBI+PBI"? Will this be $\mathrm{X}$ ?

No

$\square$ Yes (explain again that respondent will have to pay the special premium offer, X-500, not X)

- $\quad \ldots$ and the special premium offer is $\mathrm{X}+200$, then will you still be able to purchase WBI+PBI at $\mathrm{X}+200$ ?

Yes (explain again that respondent cannot purchase the product at a discounted price higher than X) $\square$ No

Do you want to change your bid on any of the insurance products? [Correct max prices on card if respondent has any changes to make.]

Procedures practice round:

Take picture of practice scratch card showing the amounts indicated for each product but BEFORE scratching off any of the boxes. 
Now please go ahead and scratch off the grey boxes. [Enter information of the scratched information: Product and special premium offer]

The selected product was: ... The maximum amount you were willing to pay for it was: Rs. X.

[IF LOWER THAN SPECIAL PREMIUM OFFER] This is LOWER than the special premium. If this were the real round, you would NOT be able to purchase this product at the special premium. What if the special premium offer were Rs. ... (amount right below X)? In that case, you would have purchased the product at Rs. ... (amount right below $\mathrm{X})$.

[IF SAME/HIGHER THAN SPECIAL PREMIUM OFFER] This is HIGHER THAN/EQUAL TO the special premium. If this were the real round, you would be purchasing this product at the special premium of: Rs. ...

Do you have any questions about this procedure? [Take picture of practice scratch card ... AFTER scratching off all of the boxes]

COMPARISONS You are willing to pay more for ' $X X X$ ' than for 'YYY'. What is the main reason for this? [DO NOT READ, only mark the answer that farmer mentions]

\section{A. WEATHER INSURANCE NO PICTURES VS WEATHER INSURANCE + TAKING PICTURES}

$\square$ My field is too far away to take pictures $\square$ Difficulty in using a smartphone $\square$ Taking pictures is a waste of time $\square$ Difficulty in using the app $\square$ Better care of crop when I visit the field more often

$\square$ Having the pictures allows me to monitor the growth of my crop $\square$ Other (Specify)

B. WEATHER INSURANCE + TAKING PICTURES VS PICTURE-BASED INSURANCE ONLY

$\square$ Weather station is too far $\square$ Picture insurance protects my crop from more risks $\square$ Pictures don't capture damage well $\square$ Pictures capture same damage as weather Insurance $\square$ High temperature and unseasonal rains is not a big risk for me $\square$ Other (Specify)

C. WEATHER INSURANCE + TAKING PICTURES VS WEATHER \& PICTURE-BASED INSURANCE

$\square$ Picture insurance protects my crop from more risks $\square$ Pictures don't capture damage well

$\square$ Pictures capture same damage as weather Insurance $\square$ Other (Specify)

*** CONTINUE JOINTLY ON FARMER'S TABLET FOR THE REAL CHOICES. MAKE SURE THAT

\section{THE SCRATCH CARDS ARE HIDDEN AWAY BEFORE THE TWO RESPONDENTS JOIN. ***}

[Let respondents pick a card, then please enter Real Card ID and re-enter the same Real Card ID. MAKE SURE THE IDS ENTERED ARE CORRECT BEFORE CONTINUING, YOU WILL NOT BE ABLE TO RETURN TO THIS SCREEN. THEN YOU WILL SEE THE QUESTION: "ARE YOU SURE YOU ARE HOLDING THE CARD WITH ID \# ...? THIS IS YOUR LAST CHANCE TO GO BACK AND CORRECT.”]

Which product is on the left-most side of the card? $\square$ WBI only $\square$ PBI only [if not the same order as in the practice round, say: "Please note: The ordering on this card is different than on the card in the practice round. Make the respondent aware of this."]

Now, for each product, from left to right: You will now decide how much to pay for ... (name product) Please think carefully, and tell me: What is the maximum amount that you would be willing to pay for this product? [Check to make sure that respondent is willing and able to purchase at that price October $31 \mathrm{st}$, and that respondent is not willing to pay more if the special premium offer is higher. Then ask respondent to write down amounts.] 


\section{Plot to be insured}

a) What is the plot to be insured? [SELECT FROM LIST] [Make sure that the farmer knows land number, or can get the land number.]

b) Who owns this plot? [SEE CATEGORIES] [Insurance policy, cheque with payment and copy of cancelled cheque / bank passbook are in the name of the same person.]

Take picture of real scratch card ... showing the amounts indicated for each product but BEFORE scratching off any of the boxes. Enter the amounts in the tablet.

Now please go ahead and scratch off the grey boxes. [Enter information of the scratched information: Product and special premium offer]

The selected product was: ... The maximum amount you were willing to pay for it was: Rs. ... [THEN READ:

- UNFORTUNATELY, as this amount is LOWER than the special premium, you will NOT be able to purchase this product $\mathrm{OR}$

- CONGRATULATIONS! As this amount is HIGHER THAN/EQUAL TO the special premium, you will be purchasing this product at the special premium of: ... ]

Take picture of real scratch card ... AFTER scratching off the boxes. 


\section{Appendix B. Additional Figures and Tables}

\section{Table B1. Farmers' experience with PBI protocol}

Panel A. Challenges faced while taking pictures

\begin{tabular}{lcc}
\hline \hline & \multicolumn{2}{c}{ Faced challenge } \\
\hline GPS accuracy problem & 452 & $65.5 \%$ \\
Phone stopped working & 97 & $14.1 \%$ \\
Glare from sun made it difficult to look at the screen & 44 & $6.4 \%$ \\
Did not have the time & 20 & $2.9 \%$ \\
Lack of storage memory in phone & 3 & $0.4 \%$ \\
Did not understand how to use the app & 2 & $0.3 \%$ \\
Did not know how to frame the picture & 2 & $0.3 \%$ \\
\hline
\end{tabular}

Panel B. Farmer feelings towards aspects of taking pictures

\begin{tabular}{lcccccc}
\hline \hline & $\begin{array}{c}\text { Really } \\
\text { like it }\end{array}$ & $\begin{array}{c}\text { Like it a } \\
\text { lot }\end{array}$ & Indifferent & $\begin{array}{c}\text { Dislike } \\
\text { it }\end{array}$ & $\begin{array}{c}\text { Really } \\
\text { dislike it }\end{array}$ & Total \\
\hline Taking pictures myself & $24.1 \%$ & $42.3 \%$ & $29.1 \%$ & $4.1 \%$ & $0.4 \%$ & $100.0 \%$ \\
Having to take pictures 3 times per week & $20.1 \%$ & $40.6 \%$ & $29.6 \%$ & $9.3 \%$ & $0.4 \%$ & $100.0 \%$ \\
Visiting plot often to take pictures & $20.6 \%$ & $38.8 \%$ & $31.2 \%$ & $9.0 \%$ & $0.4 \%$ & $100.0 \%$ \\
Answering short questionnaire after taking a picture & $17.0 \%$ & $41.0 \%$ & $31.0 \%$ & $10.4 \%$ & $0.6 \%$ & $100.0 \%$ \\
Having to take the picture between 10am and 2pm & $7.0 \%$ & $39.6 \%$ & $33.0 \%$ & $18.8 \%$ & $1.6 \%$ & $100.0 \%$ \\
\hline
\end{tabular}

Panel C. Perceived advantages from taking pictures

\begin{tabular}{lcccc}
\hline & \multicolumn{2}{c}{$\begin{array}{c}\text { Reported } \\
\text { experiencing }\end{array}$} & \multicolumn{2}{c}{$\begin{array}{c}\text { Reported it as } \\
\text { main advantage }\end{array}$} \\
\hline Detected problems in my crop more often & 357 & $51.7 \%$ & 60 & $16.8 \%$ \\
Received insurance coverage & 581 & $84.2 \%$ & 212 & $36.5 \%$ \\
Received the monthly data pack & 503 & $72.9 \%$ & 31 & $6.2 \%$ \\
Received a new smartphone & 508 & $73.6 \%$ & 234 & $46.1 \%$ \\
Other farmers were interested & 454 & $65.8 \%$ & 39 & $8.6 \%$ \\
\hline
\end{tabular}




\section{ALL IFPRI DISCUSSION PAPERS}

All discussion papers are available here

They can be downloaded free of charge

INTERNATIONAL FOOD POLICY RESEARCH INSTITUTE

www.ifpri.org

IFPRI HEADQUARTERS

1201 Eye Street, NW

Washington, DC 20005 USA

Tel.: +1-202-862-5600

Fax: +1-202-862-5606

Email: ifpri@cgiar.org 